PRZEGLĄD NAUK HISTORYCZNYCH 2020, R. XIX, NR 2

https://doi.org/10.18778/1644-857X.19.02.02

\title{
Medale koronacyjne Augusta II Wettyna w konfrontacji ze współczesnymi dziełami sztuki malarskiej i graficznej oraz ze spuścizną medalierska pozostała po Janie III Sobieskim Uwagi ikonograficzne
}

Streszczenie. Autor opisuje 16 przykładów dzieł sztuki medalierskiej, malarskiej, graficznej i rzeźbiarskiej mających związek z tytułowymi medalami. Jak wykazuje autor, podstawowym celem przekazu propagandowego wszystkich przedstawionych $\mathrm{w}$ artykule medali było uzasadnienie praw dotychczasowego elektora saskiego do tronu polskiego. Odbiorca po nawet pobieżnym zapoznaniu się $z$ przedstawionym materiałem medalierskim mógł utwierdzić się w przekonaniu co do znakomitego pochodzenia Augusta II i jego antenatów (np. medal, datowany na 1697 rok i sygnowany na awersie: C. W. [Christian Wermuth?]), licznych przymiotów panującego utożsamianego z Herkulesem (np. medal autorstwa Georga Hautscha $z 1697$ r.) czy heraldycznych związków między herbem Wettynów a oficjalnymi emblematami Korony i Litwy (np. niesygnowany medal z 1697 r.). Autor ponadto wyodrębnił i szczegółowo przeanalizował medale o charakterze: heraldycznym, mitologiczno-alegorycznym, emblematycznym i genealogicznym. Wyjaśnił również powody, dla których w zachowanej spuściźnie medalierskiej po Auguście II przeważają medale, na których władca saski został utrwalony w stroju zachodnioeuropejskim, nie zaś - jak w przypadku prac medalierskich wykonywanych na rozkaz dworu królewskiego Sobieskich - w ubiorze wzorowanym na antycznym.

Słowa kluczowe: medal, awers, rewers, August II Wettyn, koronacja.

*Wydział Nauk Historycznych i Społecznych, e-mail: janrokita1@gmail.com 
J

ak dotąd medale koronacyjne Augusta II Wettyna nie były przedmiotem żadnej pogłębionej analizy. Wzmianki o medalach były zamieszczane w katalogach wydawanych przy okazji kolejnych okolicznościowych wystaw. Wymienić w tym miejscu należy choćby katalog wystawy Pod jedna korona. Kultura i sztuka $w$ czasach unii polsko-saskiej, Zamek Królewski w Warszawie, 26 czerwca - 12 października 1997. Wzmiankowane pobieżne opisy niewiele jednak wnosza do naszych badań. Mimo upływu lat wartość naukową wciąż mają natomiast dwie prace: pierwsza, autorstwa Edwarda Raczyńskiego, Gabinet medalów polskich oraz tych, które się dziejów Polski tycza poczawszy od najdawniejszych aż do końca panowania Jana III (1513-1696) ${ }^{2}$ oraz druga, napisana przez Edwarda Hutten-Czapskiego, Catalogue de la collection des médailles et monnaies polonaises du comte E. Hutten-Czapski $i^{3}$

W badaniach nad związkami między medalierskimi a graficznymi wizerunkami Augusta II pomocne moga okazać się także prace Ewy Łomnickiej-Żakowskiej: Graficzne portrety Augusta II i Augusta III Wettynów w zbiorach Muzeum Narodowego w Warszawie i Grafika portretowa epoki saskiej $w$ Polsce $w$ relacji $z$ późnobarokowa grafika europejska ${ }^{4}$.

Celem artykułu jest udzielenie odpowiedzi na pytanie, jaka tematykę reprezentuja medale koronacyjne zwiazzane $z$ osoba Augusta II Wettyna, oraz próba odnalezienia wcześniejszych przykładów dzieł sztuki medalierskiej, malarskiej, graficznej oraz rzeźbiarskiej wykazujących bliższe lub dalsze podobieństwo do numizmatów emitowanych z rozkazu dworu saskiego. Środkiem służacym do osiągnięcia opisanego celu będzie analiza dostępnych źródeł ikonograficznych.

1 Pod jedna korona. Kultura i sztuka $w$ czasach unii polsko-saskiej, Zamek Królewski w Warszawie, 26 czerwca- 12 października 1997, red. M. Męclewska, B. Grątkowska-Ratyńska, Warszawa 1997.

${ }^{2}$ E. Raczyński, Gabinet medalów polskich oraz tych, które się dziejów Polski tycza poczawszy od najdawniejszych aż do końca panowania Jana III (15131696), t. I, Wrocław 1838; idem, Gabinet medalów polskich oraz tych, które się dziejów Polski tycza począuszy od wstapienia na tron Augusta II aż do zgonu syna jego Augusta III (1697-1763), t. II, Wrocław 1841.

${ }^{3}$ E. Hu t t e n-C za p s ki, Catalogue de la collection des médailles et monnaies polonaises du comte E. Hutten-Czapski, t. I-V, St. Petersbourg-Cracovie 1871-1916.

${ }^{4}$ E. Łomnicka-Żakowska, Graficzne portrety Augusta II I Augusta III Wettynów w zbiorach Muzeum Narodowego w Warszawie, Warszawa 1997; eadem, Grafika portretowa epoki saskiej $w$ Polsce $w$ relacji $z$ późnobarokowa grafika europejska, Warszawa 1997. 
Śmierć cieszącego się duża popularnością wśród szlachty Jana III Sobieskiego i zwycięstwo elekcyjne Fryderyka Augusta, dotychczasowego elektora saskiego, spowodowały, że medalierzy działający na zlecenie koronowanego 15 września 1697 r. w katedrze na Wawelu monarchy polskiego musieli sprostać wielu nowym dylematom. Po pierwsze, należało udowodnić, że dotychczasowy elektor saski jest godnym następcą Jana III Sobieskiego. W przeciwieństwie jednak do zmarłego poprzednika medalierzy działajacy na dworze saskim prawie nigdy nie upamiętniali Augusta II Wettyna i jego syna zgodnie $z$ wytycznymi mody sarmackiej. Wręcz przeciwnie, medalierskie wizerunki dwóch Sasów na tronie polskim powstawały zgodnie $z$ najnowszymi trendami mody zachodnioeuropejskiej. Ten stan rzeczy wynikał zapewne $z$ tego, że zarówno August II, jak i August III nigdy nie wyrzekli się praw do sprawowania władzy nad Saksonią.

Ważnym etapem $\mathrm{w}$ drodze do osiagnięcia korony polskiej przez Fryderyka Augusta Wettyna była konwersja na katolicyzm 2 czerwca 1697 r. w Wiedniu ${ }^{5}$. Przyjęcie nowej wiary nie spowodowało oczywiście utraty wpływów w Saksonii, w której władze sprawował Wettyn za pomoca Tajnej Rady. Ostatecznie jednak to nie dzięki religijnym deklaracjom, a wsparciu finansowemu bankierów - Issachara Berenda Lehmanna i Samsona Wertheimera - oraz politycznemu cara Piotra I, który jednocześnie sprzeciwiał się kontrkandydaturze księcia Franciszka Ludwika Burbon-Conti, zawdzięczał Fryderyk August koronę polską.

Dnia 27 czerwca 1697 r. większość szlachty zgromadzonej na sejmie elekcyjnym trwajacym od 15 maja do 28 czerwca $1697 \mathrm{r}$. poparła francuskiego kandydata do korony polskiej - Franciszka Ludwika Burbon-Conti (cieszącego się przychylnością Ludwika XIV, począwszy od lipca 1696 r.). W następstwie rezultatów elekcji władca tego samego dnia prymas interrex Michał Radziejowski ogłosił księcia Conti królem polskim. W odpowiedzi analogiczna czynność na korzyść Augusta II Wettyna wykonał biskup kujawski Stanisław Dambski, mimo braku odpowiednich prerogatyw (nie pełnił funkcji interrexa) oraz oczywistego faktu, że Wettyn uzyskał podczas elekcji zaledwie 13641 głosów szlachty przekupionej przez wysłanników cara Piotra I Romanowa. Korzystając jednak $z$ długiej nieobecności nowego władcy elekcyjnego w kraju, August II Wettyn z poparciem korpusu kniazia Michaiła

\footnotetext{
${ }^{5}$ J. Staszewski, August II Mocny, Wrocław 1998, s. 47-53.
} 
Grigoriewicza Romodanowskiego zdobył 31 lipca 1697 r. Kraków (po przekupieniu Franciszka Wielopolskiego - stronnika księcia Contiego), gdzie po zdobyciu insygniów koronacyjnych przechowywanych w wawelskim skarbcu i zaprzysiężeniu pactów conventów, 15 września 1697 r. został koronowany na króla polskiego przez biskupa Dąmbskiego ${ }^{6}$. Dopiero 26 września książę Conti na czele sześciu okrętów francuskich z 8000 żołnierzy pod komenda Jeana Barta wpłynął do redy portu w Gdańsku (podróż trwała od 3 września 1697 r.) $)^{7}$. Napisany za namową biskupa płockiego Andrzeja Stanisława Załuskiego manifest księcia, datowany na 5 października tego roku i skierowany do prymasa Michała Radziejowskiego, senatorów i szlachty, w którym informował o swoim przybyciu i zapewniał o poszanowaniu praw Rzeczypospolitej, na niewiele jednak się zdał wobec koronacji Augusta II 15 września 1697 r. W obawie przed zbliżającymi się do Gdańska wojskami wiernymi Augustowi II Wettynowi 9 listopada Conti udał się w droge powrotna i do Rzeczypospolitej nigdy nie próbował już powrócić ${ }^{8}$.

Ze względu na tematykę medali, których przekaz miał utwierdzać prerogatywy monarsze Augusta II w najbardziej niespokojnych pierwszych miesiącach i latach po elekcji, nie bez znaczenia wydaje się działalność królewskich opozycjonistów z prymasem Radziejowskim na czele, którzy zawiązali we wrześniu 1697 r. rokosz łowicki. Dopiero sejm obradujacy od 16 czerwca do 30 lipca 1699 r. oficjalnie uznał pretensje dynastyczne Augusta II - w zamian za złożenie powtórnej przysięgi na pacta conventa, usunięcie $z$ kraju wojsk saskich $z$ wyjątkiem 1200 gwardzistów i złożenie obietnicy niesprowadzania do kraju nowych oddziałów ${ }^{9}$.

Przegląd zachowanych do dziś numizmatów należy rozpoczać od medalu dowodzacego, że August II Wettyn, podobnie jak Jan III Sobieski, bardzo często kazał artystom pracujacym na jego zamówienie szukać wzorców inspiracji w ikonografii antycznej. Mowa $\mathrm{w}$ tym miejscu o medalu nieznanego autora pozbawionym daty

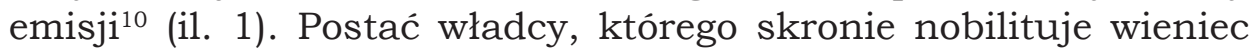
laurowy, ukazana na awersie w popiersiu i ujęciu profilowym,

6 Ibidem.

7 Ibidem, s. 12.

8 Ibidem, s. 18.

9 P. Napierała, Die polnisch-sächsische Union (1697-1763) - Polens letzte Hoffnung - Sachsens Traum von der Macht, [w:] Polen un Deutschland Zusammenleben und-wirken, Poznań 2006, s. 60-66.

10 E. Raczyński, op. cit., t. II, poz. 262. 
przypomina bardziej wizerunki cesarzy rzymskich umieszczane np. na starożytnych monetach. O którego $z$ władców imperium rzymskiego chodziło medalierowi, może sugerować napis otokowy: AVGVSTVS tożsamy jednocześnie $z$ imieniem władcy nowożytnego z dynastii Wettynów, przyjętym podczas uroczystości koronacyjnych na Wawelu w Krakowie 16 września 1697 r.

Ze spuścizny numizmatycznej zachowanej po cesarzu Oktawianie Auguście (Gaiuszu Iuliuszu Caesarze Octavianusie) warto wymienić zwłaszcza monetę o wartości złotego aureusa wybitą między 19 a 18 r. p.n.e w Pergame (Pergamonie) ${ }^{11}$. Awers monety zawiera popiersie młodego cesarza w prawym profilu, pozbawione jednak wieńca laurowego, wraz $z$ napisem otokowym AVGVSTVS. Ten sam atrybut władzy cesarskiej pojawił się na awersach szeregu innych monet $z$ tego okresu, $\mathrm{np}$. na pierwszej stronie złotego aureusa, datowanego między 11 a 10 r. p.n.e. i wybijanego w Lugdunum (Lyonie) ${ }^{12}$. W tym przypadku podobizna panującego została przedstawiona również $\mathrm{w}$ popiersiu $\mathrm{w}$ prawym profilu. Odmienna jest jednak inskrypcja otokowa: AVGVSTVS - DIVI F. Niewatpliwie więc medalierzy królewscy potrafili bardzo sprawnie wykorzystać istniejące podobieństwa między imieniem nowego władcy polskiego a imieniem cesarza rzymskiego.

Rewers medalu anonimowego autora zaopatrzony został w wyobrażenie orła piastowskiego $z$ korona clausa unoszaca się nad jego głowa oraz uwzględnionymi na jego piersiach herbem Wettynów - mieczami elektorskimi i herbem rucianym Wettynów. Funkcję komentarza stanowi napis odnoszacy się do zakresu władzy królewskiej Augusta II: D[ei] G[ratia] REX POL[oniae] ET EL[ector] SAX[oniae] (Z Bożej łaski król polski i elektor saski).

Istnieje niedatowana odmiana powyższego medalu, również sporządzona przez nieznanego twórcę ${ }^{13}$ (il. 2). Awers powtórzono bez zmian. Natomiast na rewersie medalier uwiecznił koronę clausa, przynależną tylko suwerennym władcom zgodnie $z$ zasada rex imperator in regno suo. Napis otokowy: D[ei] G[ratia] REX ET EL[ector] (Z Bożej łaski król i elektor) miał przypominać odbiorcy o wydarzeniach z 27 kwietnia 1694 i 27 czerwca 1697 r. Zarówno niewielkie

11 Własność prywatna. Przedmiot wystawiony na aukcje antykwariatu „Numismatica Genevensis" (Genewa) 27 XI 2012 r. (aukcja 7, kat. nr 321).

12 Własność prywatna. Przedmiot wystawiony na aukcje antykwariatu „H.D. Rauch GmbH” (Wiedeń) 23 IV 2008 r. (aukcja 82, kat. nr 213).

${ }^{13}$ E. Raczyńs ki, op. cit., t. II, poz. 263. 
rozmiary krążka, jak i analiza formalna jego przekazu i kompozycji artystycznej wskazują, że wzmiankowane dzieło medalierskie mogło być rozdysponowywane pomiędzy królewskimi poddanymi np. podczas uroczystości koronacyjnych.

Zapewne $z$ tego samego okresu wyróżnić można także niesygnowany medal z 1697 r. Awers wypełnia postać królewska w popiersiu zwróconym w prawo $^{14}$ (il. 3). Monarcha ma na sobie, oprócz peruki, antyczna zbroję $z$ paskami pteryges wystajacymi spod naramiennika, stalowy kirys oraz płaszcz udrapowany na wysokości klatki piersiowej. Na rewersie $z$ kolei upamiętniono królewską koronę clausa, do której komentarz stanowi napis w otoku: HANC DEVS IPSE DEDIT (Tę sam Bóg dał). Drugi to już przypadek, kiedy realizujący królewskie zlecenie Augusta II medalierzy utrwalili najważniejsze $z$ królewskich insygniów koronacyjnych. Działanie to nie miało jednak tylko charakteru stricte okolicznościowego związanego $z$ aktem sakry Augusta II, lecz było raczej nawiązaniem do tradycji znanej w medalierstwie polskim od czasów Jana III Sobieskiego. Analizując bowiem spuściznę medalierska po poprzedniku pierwszego Sasa na polskim tronie, udało się odnaleźć dwa numizmaty, na których korona clausa miała oznaczać przymioty królewskie. Należy więc wymienić na pierwszym miejscu anonimowy żeton koronacyjny z 1676 r., na którego rewersie powyżej stepowej panoramy Chocimia i tarczy Sobieskich Janina widnieje wymienione insygnium władzy monarszej ${ }^{15}$. Drugi $z$ numizmatów koronacyjnych autorstwa Höhna (Hoehna) mł., także z około 1676 r.,

14 Ibidem, poz. 277.

15 Kraków, Muzeum Narodowe, nr inw. VII-Md-631 MNK; E. Raczyński, op. cit., t. II, poz. 193; E. Hutten-Czapski, op. cit., t. I, poz. 7763; W. Bartynowski, Teki Bartynowskiego: Medale z czasów Jana III, b.m.w. [XIX/XX w.], poz. I.G. 18252; M. Gu mow ski, Sztuka medaljerska $w$ Polsce i jej rozkwit, Warszawa 1924, s. 62; J. M a n th ey, Le bienheureux Innocent XI et La Pologne „Boulevard de la Chrétienté” sur les medailles commemoratives: de „Dextera tua Domine percussit inimicum” (1683) à „Pax fundata cum Moschis” (1686), èd. J. Gawlina, Roma 1956, s. 22; C. Kamiński, W. Kowalczyk, Medale i medaliony polskie $i$ zwiazane z Polska. Katalog wystawy, Warszawa 1969, s. 121-136, poz. 58; Chwała $i$ sława Jana III $w$ sztuce $i$ literaturze. Katalog wystawy jubileuszowej $z$ okazji trzechsetlecia odsieczy wiedeńskiej. Warszawa (Wilanów) wrzesień-grudzień 1983, red. W. Fijałkowski, J. Mieleszko, Warszawa 1983, s. 210-211, kat. nr 179; Odsiecz wiedeńska. Wystawa jubileuszowa w Zamku Królewskim na Wawelu $w$ trzechsetlecie bitwy. t. I, red. A. Franaszek, K. Kuczman, Kraków 1990, s. 167, kat. nr 177; M. Stahr, Medale polskie i z Polska zwiazane od XVI do XVIII wieku, Poznań 2008, s. 85, poz. 81. 
reprezentuje dużo wyższy kunszt artystyczny ${ }^{16}$. Kompozycja artystyczna rewersu została jednak w zasadzie powtórzona bez zmian (z wyjątkiem stepowej panoramy Chocimia) i uzupełniona o napis: TEGIT ET - PROTEGIT (Osłania i zabezpiecza).

Kolejny medal, również pozbawiony daty, zaopatrzony został w sygnaturę autorską: G. L. $F^{17}$ (il. 4). Na awersie medalier odtworzył młodzieńcze popiersie profilowe Augusta II w koszuli z marszczonym kołnierzem, cyzelowanej zbroi składajacej z kirysu i naramiennika folgowego wraz z zaokraglona tarczka podbita od spodu materia, płaszczu gronostajowym spiętym na lewym ramieniu broszą i koronie clausa spoczywającej na skroniach królewskich. Napis: AUG[ustus] II D[ei] G[ratia] REX POLON[iae] (August II $z$ Bożej łaski król polski) stanowi potwierdzenie królewskich prerogatyw.

Najbardziej bliska wizji medaliera zrealizowanej na pierwszej stronie opisywanej pracy wydaje się grafika portretowa Augusta $\mathrm{II}^{18}$. Wzmiankowana rycina (miedzioryt, papier żeberkowy) została wykonana pod koniec XVII w. bądź na początku XVIII w. przez rytownika Jacobusa Golego. Polski monarcha elekcyjny został sportretowany w ujęciu en trois quarts $z$ głowa zwrócona w prawo. Analizując ubiór monarchy, należy wyodrębnić nowożytna zbroję: stalowy kirys przepasany szarfą orderowa i naramiennik folgowy z tarczka, drapowany płaszcz spięty na wysokości lewego ramienia okragła broszą oraz koszulę z koronkowym żabotem na wysokości szyi. O gustach i upodobaniach człowieka epoki późnego baroku dowodzi także peruka à la lion. Na prawo, na drugim planie, artysta-rytownik odwzorował koronę clausa leżąca zapewne na postumencie bądź kwadratowym stoliku. Porównując podobiznę

${ }^{16}$ Kraków, Muzeum Narodowe (zbiory E. Hutten-Czapskiego), nr inw. VII-Md-433; Własność prywatna. Przedmiot wystawiony na aukcji Warszawskiego Centrum Numizmatycznego (WCN) 27 II 2016 r. (aukcja nr 63, kat. nr 813); E. Raczyński, op. cit., t. II, poz. 196, 199, 200 (odmiana); E. Hutten-Czapski, op. cit., t. I, poz. 2511, 2512; W. Bartynowski, op. cit., poz. I.G. 18264, I. G. 18265; M. Gumowski, op. cit., s. 62; J. Manthey, op. cit., s. 22; J. Szwagrzyk, Moneta, medal, order, Wrocław 1971, s. 28-89; Kolekcja generała Jerzego Węsierskiego. Katalog monet i medali, red. A. Białkowski, E. Tarka, S. Suchodolski, Z. Wdowiszewicz, Muzeum Narodowe, Warszawa 1974, poz. 2562; Chwała $i$ sława Jana III..., s. 210, kat. nr 178; Odsiecz wiedeńska..., t. I, s. 167-168, kat. nr 178.

17 Własność prywatna. Przedmiot wystawiony na aukcje antykwariatu „Gabinet numizmatyczny Damiana Marciniaka” (Gdańsk) 10 II 2018 r. (aukcja 4, kat. nr 1359), E. Raczyński, op. cit., t. II, poz. 264.

${ }_{18}$ Warszawa, Muzeum Narodowe, nr inw. 79199, E. Łomnicka-Żakowska, Graficzne portrety..., s. 56, poz. 11 . 
władcy ukazana na obydwu kompozycjach: medalierskiej i graficznej, należy zwrócić uwagę na istniejące rozbieżności. Wzmiankowany płaszcz, mimo że podobnie udrapowany i spięty na lewym ramieniu brosza, na rycinie $\mathrm{w}$ dużo większym stopniu zakrywa kirys oraz tarczkę naramiennika podbitą od spodu materią. Medalier, również w przeciwieństwie do rytownika, nie zdecydował się uwzględnić w swojej pracy szarfy orderowej oraz koszuli z żabotem. W końcu identyczna korona clausa, która na miedziorycie została wiernie odwzorowana, na drugim planie, na awersie numizmatu nobilituje głowę królewską. W przypadku ustawienia głowy królewskiej w prawym profilu (na awersie medalu) uprawnione jest mówienie o celowym działaniu ze strony medaliera chcącego tym działaniem nawiązać do podobizn cesarzy rzymskich umieszczanych na starożytnych monetach ${ }^{19}$.

$\mathrm{Na}$ rewersie medalu $z$ sygnatura G. L. F. natomiast oglądajacy dostrzeże insygnia władzy Augusta II: koronę clausa, berło oraz dwa miecze elektorskie nawiąujace do herbu elektorów Saksonii, spoczywające na postumencie w kształcie ściętego filaru bądź kolumny. Napis u góry: HONORE, TIMORE (Czcią, bojaźnią) dotyczy powinności poddanych wobec nowego władcy, którego uzewnętrznieniem władzy są wspomniane insygnia.

Istnieje również niedatowana odmiana powyższego medalu, autorstwa monogramisty G. L. F. ${ }^{20}$ Rewers wraz z sygnatura autorska u dołu oddano bez zmian. Natomiast na awersie obok analogicznego reprezentacyjnego wizerunku władcy medalier ułożył inna inskrypcję otokową: FRID[ericus] AUG[ustus] II REX POL[oniae] EL[ector] SAX[oniae] (Fryderyk August II król polski, elektor saski).

Różnica między obydwoma inskrypcjami sprowadza się przede wszystkim do tego, że twórca odmiany medalu zrezygnował z tradycyjnej formuły Dei Gratia. Formułę tę znajdujemy również na inskrypcjach medali innych władców europejskich, m.in. cesarza austriackiego i króla arcychrześcijańskiego. W XVII-wiecznej Rzeczpospolitej o obiorze nowego monarchy zawsze decydowała szlachta. Niemniej szlacheccy elektorzy głęboko wierzyli, że decyzję na polu elekcyjnym podejmowali pod wpływem Boga, stąd formuła ta była jak najbardziej akceptowana i uwzględniana m.in. w inskrypcjach medali poprzednika Augusta III - Jana III Sobieskiego.

${ }^{19}$ M. Stahr, Wstep, [w:] eade m, Medale Wazów w Polsce (1587-1668), Wrocław-Warszawa-Kraków 1990, s. 7-9.

20 E. Raczyński, op. cit., t. II, poz. 265. 
Kolejny medal, zaprojektowany przez Georga Hautscha w roku 1697, gloryfikował przymioty Augusta II Wettyna znanego jako Herkules Saski ${ }^{21}$ (il. 5). Na awersie znajduje się podobizna monarchy $\mathrm{w}$ koszuli $\mathrm{z}$ marszczonym kołnierzem, kirysie urozmaiconym motywem roślinnym wraz $z$ naramiennikiem folgowym oraz płaszczu gronostajowym spiętym na wysokości lewego ramienia okragła brosza. Napis otokowy: FRID[ericus] AUG[ustus] D[ei] G[ratia] ELECT[or] SAX[oniae] IN REGEM POLON[iae] ELECT[us] 1697 (Fryderyk August $z$ Bożej laski elektor saski na króla obrany 1697 r.) informował zaś odbiorcę o zakresie władzy elektorskiej i królewskiej Augusta II Wettyna.

Podczas kwerendy spuścizny ikonograficznej pozostałej po Auguście II Wettynie udało się odnaleźć portret graficzny, dla którego twórcy medal stanowił niezastapiony wzorzec. Wymieniona rycina powstała około 1702 r. w warsztacie Johanna Striberga mł. (w drukarni Jacoba Koppmayera) ${ }^{22}$. Owalny portret monarchy ukazany $\mathrm{w}$ górnej części ryciny powyżej szarfy $z$ napisem: PROVINCIARVM POLONIAE GEOGRA. DESCRIPTIO podtrzymywany jest przez personifikację Polonii - mężczyznę w przylegającej do ciała szacie do kolan $z$ krótkimi rękawami, hełmie $z$ pióropuszem (na głowie) i rzemiennych sandałach, dzierżacego w prawym ręku tarczę $z$ podwójnymi emblematami państwowymi: Korony i Litwy, w lewym ręku zaś miecz oraz personifikację Saksonii - niewiastę w szacie $z$ wycięciami zamiast rękawów, obszernym dekoltem i hełmie $z$ pióropuszem (na głowie), trzymającej w prawym ręku tarczę $z$ herbami miast saskich. Wizerunek monarchy wewnątrz medalionu niewiele odbiega od jego medalierskiego odpowiednika. Królewski ubiór składa się z koszuli z marszczonym kołnierzem, stalowego kirysa $z$ widocznym naramiennikiem folgowym oraz płaszcza podbitego gronostajem i spiętego na lewym ramieniu broszą. Rytownik w przeciwieństwie do medaliera zdecydował się jedynie uhonorować dodatkowo skronie panującego wieńcem laurowym. Zbliżony pozostaje natomiast napis otokowy na medalionie: DG FRID AUG REX POL SAC ROM IMP ARCHIM ET ELECT DUX SAX ICMA \& W.

${ }^{21}$ Własność prywatna. Przedmiot wystawiony na aukcji „Antykwariat Michał Niemczyk" (Warszawa) 23 X 2018 r. (aukcja 1, kat. nr 4), E. Raczyński, op. cit., t. II, poz. 266.

${ }^{22}$ Warszawa, Muzeum Narodowe, nr inw. 62182, E. Łomnicka-Żakowska, Graficzne portrety..., s. 250, poz. 106. 
Poniżej, w środkowej części kompozycji rytownik uwzględnił następujące personifikacje: Herkulesa - mężczyzny z narzuconą na ramiona i głowę skóra lwa nemejskiego, zaopatrzonego w maczugę (w lewym ręku) i kamienną tablicę $z$ napisem: VD M IAE oraz spoglądającego na medalion $z$ wizerunkiem królewskim Augusta II i depczącego powalonego na ziemię wroga Rzeczpospolitej (w środku kompozycji); niewiasty symbolizujacej zapewne majestat królewski odzianej w płaszcz gronostajowy, długa suknię spodnią oraz prezentujaca jabłko $z$ napisem: POLONIA (w prawym ręku) i berło (w lewym ręku), również depczącej powalonego rzymskiego wojownika w hełmie $z$ pióropuszem, karacenie i naramienniku $z$ paskami pteryges, usiłującego bezskutecznie bronić się za pomoca krótkiego rzymskiego miecza gladius (w lewej części kompozycji); Bellony - niewiasty w hełmie na głowie, stalowym kirysie, szacie spodniej z krótkimi, bufiastymi rękawami, za pomocą włóczni godzącej w skrzydlatego potwora o sześciu głowach, zapewne w hydrę lernejską (w prawej części kompozycji).

Rewers natomiast podporządkowano wykazaniu, że wybór elektora saskiego na polskiego władcę elekcyjnego zyskał akceptację większości szlacheckich poddanych. W celu realizacji tego zadania posłużono się tematyką mitologiczną. Dwoje głównych bohaterów kompozycji - Herkulesa oraz personifikację Polonii ukazano w pozycjach stających. Dzięki zastosowaniu elementów aktualizacji, takich jak kompletna XVIII-wieczna zbroja, nie ma wattpliwości, że główna intencją medaliera było utożsamienie Augusta II właśnie $z$ Herkulesem. W skład wzmiankowanej zbroi wchodzą: kirys, nałokcice, zarękawie, nabiodrki, nakolanniki, nagolennice i trzewiki. Natomiast do atrybutów kojarzonych $z$ Herkulesem trzeba zaliczyć skórę ( $z$ pyskiem) lwa nemejskiego narzucona na lewe ramię oraz maczugę zlokalizowaną w prawym ręku i opartą o ziemię. Pod stopami antycznego bohatera spoczywa hydra lernejska. Oddająca pokłon zwycięskiemu władcy personifikacja Polonii to niewiasta odziana $\mathrm{w}$ pofałdowana materię $\mathrm{z}$ szalem trzymająca $\mathrm{w}$ prawym ręku koronę clausa (na poduszce). Do sceny tej odnosza się dwa napisy: NEC ME LABOR ILLE GRAVABIT (Praca ta mię nie obciąży) (w otoku), HERCULI SAXONICO (Herkulesowi saskiemu) (w odcinku) oraz EXPETITUR QUEM VOTA DECENT REX SAXO POLONIS (na rancie). Twórca inskrypcji, używając terminu HERCULI SAXONICO, pragnął przypomnieć oglądajaccemu o nadzwyczajnej 
tężyźnie fizycznej, jaką odznaczał się August II Wettyn noszący przydomek „Mocny”.

Następny medal o wartości dukata koronacyjnego, pozbawiony sygnatury twórcy i pochodzący z 1697 r., również należy połączyć $z$ data obioru Augusta II Wettyna na władcę polskiego ${ }^{23}$. Główną postacią upamiętnioną na awersie jest nieznany jeździec (zapewne królewski) z głową zwróconą w kierunku przeciwnym do kierunku jazdy, na wspiętym koniu w stroju staropolskim: futrzanym płaszczu, żupanie $z$ długimi rękawami oraz pętlicami i guzami, sięgającym aż po kostki, oraz nałożonym na głowę kołpaku z przypięta kita piór. W lewym ręku jeździec dzierży buzdygan, w prawym zaś ręku ściska cugle. Na wyposażeniu jeźdźca pozostaje jeszcze pistolet w olstrach (na wysokości uda królewskiego). Natomiast samego wierzchowca artysta uchwycił w nierealistycznej pozie. Oparciem dla kopyt przednich uniesionych do góry sa kopyta tylne wsparte o ziemię.

Wartość opisywanego numizmatu polega na istnieniu ryciny stanowiącej istotny punkt odniesienia dla medaliera. Mowa w tym miejscu o miedziorycie (papier żeberkowy z filigranem), autorstwa nieokreślonego rytownika, datowanym na okres po $1697 \mathrm{r}^{24} \mathrm{i}$ wzorowanym na graficznym przedstawieniu Jana III Sobieskiego ${ }^{25}$. August II Wettyn został utrwalony przez rytownika podczas siedzenia na wspiętym koniu, którego para tylnych kopyt stanowi oparcie dla pary przednich kopyt unoszacych się w powietrzu. Głowa bohatera kompozycji graficznej pozostaje odwrócona w prawo. Monarcha ma na sobie suknię spodnią - długi, wzorzysty żupan $z$ pętlicami i guzami, spięty pasem $z$ kamieniami szlachetnymi oraz narzucony nań, podbity futrem i odpowiednio udrapowany płaszcz spięty pod szyją okragła zapona. Nakrycie głowy Augusta II stanowi kołpak $z$ klejnotem oraz egreta. Za ważny atrybut świadczący o militarnych kompetencjach portretowanego należy uznać buzdygan zlokalizowany w prawym ręku władcy. W lewym ręku panujący ściska $z$ kolei zapewne cugle. Funkcję siedziska królewskiego pełni czaprak $z$ wyszywana dekoracja imitująca kamienie szlachetne,

${ }^{23}$ Własność prywatna. Przedmiot wystawiony na aukcji „Antykwariat Michał Niemczyk" (Warszawa) 21 X 2017 r. (aukcja 12, kat. nr 188), E. Raczyński, op. cit., t. II, poz. 267.

${ }^{24}$ Warszawa, Muzeum Narodowe, nr inw. 61180, E. Ło mnicka-Żakowska, Graficzne portrety..., s. 196, poz. 81 .

${ }^{25}$ Warszawa, Muzeum Narodowe, nr inw. 62714. 
urozmaicony na obrzeżeniu frędzlami. Na wysokości królewskiego kolana znajduje się przypięty zapewne do rzędu końskiego pistolet w olstrach. W tle wizerunku monarchy rytownik sporzadził podobiznę murów miejskich Krakowa $z$ fortyfikacjami Zamku na Wawelu.

$Z$ pewnością między kompozycja graficzną a medalierską występuja liczne analogie, do których zaliczyć trzeba wymieniony ubiór władcy: futrzany płaszcz, żupan, czapkę $z$ klejnotem i egretą oraz atrybuty wojenne: buzdygan i pistolet w olstrach. Także królewskie siedzisko w formie czapraka oraz samo ustawienie królewskiego wierzchowca w nierealistycznej pozie w obydwu przypadkach wyglądaja podobnie. Jedynie głowa Augusta II wyobrażona na awersie medalu pozostaje całkowicie odwrócona w stronę przeciwną do kierunku jazdy wierzchowca. Medalier nie powtórzył również $z$ miedziorytu tła. $Z$ pewnościa jest $\mathrm{w}$ tym przypadku uprawnione mówienie o związku między konkretną grafika a medalem.

Nie sposób nie wspomnieć w tym miejscu o reprezentacyjnym konterfekcie malarskim wprawdzie na pewno niewybranym przez medaliera jako podstawa, jednak świadczacym o jednoznacznej przychylności monarchy dla analogicznych sposobów uwieczniania jego sylwetki za pośrednictwem medalierstwa. Mowa tu o kolejnym obrazie Augusta II Wettyna pędzla Luisa de Silvestre'a, datowanym na około $1718 \mathrm{r}^{26}$ Postać monarchy ukazano w ujęciu en trois quarts podczas siedzenia również na wspiętym wierzchowcu wraz $z$ fantastycznym wyobrażeniem twarzy nieznanej postaci, być może mitologicznej, przymocowanym na przedzie do rzędu końskiego ze złotymi sprzączkami oraz ze zwisającym poniżej frędzlem. Co ciekawe, położenie na obrazie głowy królewskiej zwróconej w przeciwnym kierunku do jazdy jest identyczne jak na awersie medalu. O wysokiej randze portretowanego dowodzi zielony czaprak z licznymi frędzlami na obrzeżeniu. Do najważniejszych elementów odzienia królewskiego należy zaliczyć widoczną fragmentarycznie na wysokości szyi biała koszulę spodnią, zbroję: kirys przepasany szeroka niebieską wstęga $z$ zawieszonym orderem Orła Białego, naramiennik folgowy, nałokcic, zarękawie, nabiodrek i nakolannik, narzucony na ramiona czerwony płaszcz podbijany od spodu centkowanym futrem, spięty na wysokości lewego ramienia podłużna brosza, czerwona materię oraz wysokie buty nałożone na ostrogi ze złotymi guzami i sprzaczką. Portretowany zaopatrzony jest w atrybut władzy dawnych dowódców rzymskich - regiment w prawym

${ }^{26}$ Drezno, Państwowe Zbiory Sztuki, Gabinet Numizmatyczny, nr inw. Gal.-Nr. 768. 
ręku. Ponadto na wysokości królewskiego uda oglądający zauważy przytroczone do siodła olstro zasłonięte ciemnozieloną materią wyszywana złotą nicią i $z$ frędzlami $u$ dołu $z$ pistoletem wewnątrz. W tle obok panoramy niezidentyfikowanego ufortyfikowanego miasta artysta namalował pożar i kłęby dymu.

Rewers medalu pozbawionego sygnatury z 1697 r. natomiast wypełniają wyobrażenia: insygnium władzy królewskiej - korony clausa, dwóch skrzyżowanych gałązek palmowych oraz napis: D[ei] G[ratia] F[ridericus] A[ugustus] E[lector] S[axoniae] EL[ectus] IN REG[em] POLONIARUM D[ie] 17/27 IUN[ii] A. 1697 (Z Bożej łaski Fryderyk August elektor saski, obrany na króla polskiego dnia $17 / 27$ czerwca 1697 r.).

Palma symbolizuje w tym przypadku sukces na polu elekcyjnym w zmaganiach $z$ konkurentem księciem francuskim Franciszkiem Ludwikiem Burbon-Conti. Fryderyk August I starania o koronę polska rozpoczał od konwersji z protestantyzmu na katolicyzm 2 czerwca 1697 r. w Wiedniu ${ }^{27}$. Elekcja królewska trwała od 15 maja do 27 czerwca 1697 r. na polach w obrębie dzisiejszej warszawskiej dzielnicy Wola. Ostatecznie 27 czerwca 1697 r. prymas Michał Radziejowski, wobec poparcia udzielonego przez większość szlachty księciu Burbon-Conti, ogłosił Wettyna królem polskim.

Do naszych czasów zachował się dukat koronacyjny autorstwa anonimowego twórcy, wykazujący podobieństwo do opisywanego medalu $^{28}$ (il. 6). Awers wypełnia podobizna, zapewne królewskiego jeźdźca, na wspiętym koniu i w antykizowanym stroju: karacenie z kwadratowym wycięciem wokól szyi ze stalowym naramiennikiem, narzuconym na prawym ramieniu szalu, tzw. rzymskim fartuszku $z$ paskami cingulum i hełmie $z$ pióropuszem. W lewym ręku jeździec dzierży regiment.

Awers medalu wykazuje bardzo duże podobieństwo do pomnika Augusta II siedzącego na wspiętym koniu lipicańskim na rynku Nowego Miasta w Dreźnie, odsłoniętego 26 listopada 1736 r., co może sugerować późniejszą niż poprzednio opisywany numizmat datę emisji ${ }^{29}$. Pomnik zaprojektował Jean Josep Vinache, odlał zaś Ludwig Wiedemann. Głowa modela zwrócona jest na wprost, zgodnie $z$ kierunkiem jazdy. August II ma na sobie również kara-

27 J. Staszewski, op. cit., s. 101.

28 Własność prywatna. Przedmiot wystawiony na aukcji „Gabinet Numizmatyczny Damian Marciniak” (Gdańsk) 2 IV 2017 r. (aukcja 2, kat. nr 245).

${ }^{29}$ Drezno, Rynek Nowego Miasta. 
cenę $z$ kwadratowym wycięciem wokół szyi, długą szatę spodnią podwinięta poniżej kolan, naramiennik $z$ paskami pteryges, tzw. rzymski fartuszek $z$ paskami cingulum, wysokie rzemienne sandały $z$ opaskami na kolanach. W lewym ręku monarchy znajduje się regiment, w prawym ręku zaś cugle. Do królewskiego pasa $z$ kamieniami szlachetnymi między karacena a tzw. rzymskim fartuszkiem przypięta jest także na rapciach pochwa $z$ tradycyjnym mieczem $z$ rękojeścia.

$\mathrm{Na}$ rewersie natomiast upamiętniono wyobrażenie korony clausa ze skrzyżowanymi mieczem i berłem wewnattrz oraz inskrypcje: REGET ET DEFENDET (będzie panował i bronił), w wierszach: D[ei] G[ratia] AUGUSTUS II CORON[atus] IN REG[em] POLON[iae] ET M[agnum] D[ucem] L[ithuaniae] D[ie] 15 SEPT[embris] A[nno] 1697 (Z Bożej łaski August II koronowany na króla polskiego i wielkiego księcia litewskiego dnia 15 września roku 1697).

Kolejny medal, autorstwa Martina Heinricha Omeisa, mimo że zgodnie $z$ zamierzeniem medaliera miał uwypuklać prerogatywy królewskie Augusta II Wettyna, na pierwszym miejscu podporządkowany był wykazaniu długich tradycji sprawowania władzy przez dynastię panujaca w Saksonii ${ }^{30}$ (il. 7). Na awersie oglądający dostrzeże podobiznę Augusta II Wettyna w kirysie $z$ naramiennikiem folgowym oraz płaszczu gronostajowym spiętym na wysokości lewego ramienia kolistą zaponą. Najważniejszy szczegół kompozycji - korona clausa spoczywa na głowie monarchy. Informacji na temat aktualnej tytulatury królewskiej dostarcza inskrypcja otokowa: D[ei] G[ratia] FRID[ericus] AUGUST[us] POLONIARUM REX SAX[oniae] DUX ET ELECT[or] (Z Bożej łaski Fryderyk August król polski, książę saski i elektor 1699).

Natomiast rewers zajmuje wizerunek Witekinda (Widukinda), władcy Angrywarów i legendarnego protoplasty dynastii Wettynów. Ubiór stanowi odzwierciedlenie poglądów współczesnych medalierowi dotyczacych wyglądu antycznego bohatera. Obok szaty spodniej z marszczonym kołnierzem możemy wyróżnić płaszcz pobity gronostajem i spięty poniżej szyi kolista zapona, którego spodnią część udekorowano motywem sześcioramiennych gwiazd. Na pasie pionowym zakończonym $z$ dwóch stron perłowaniem stanowiącym obrzeżenie płaszcza Witekinda (Widukinda) uwzględniono kamie-

30 Własność prywatna. Przedmiot wystawiony na aukcji „Fritz Rudolf Künker GmbH \& Co. KG” (Osnabrück) 28 IX 2015 r. (aukcja 266, kat. nr 1499), E. Raczyński, op. cit., t. II, poz. 268. 
nie szlachetne w oprawie. Głowę legendarnego bohatera wieńczy mitra książęca również uzupełniona kamieniami szlachetnymi. Napis otokowy: WITEKIND[us] ANGRIVARIORUM REX SAX[oniae] PROCERUM DUX (Witekind król Angrywarów, pierwszy z pomiędzy panów) zawiera rzekomą tytulaturę wspomnianej postaci. Niewątpliwie zestawienie przez artystę na dwóch stronach tego samego medalu podobizn dwóch władców - rzeczywistego i legendarnego - żyjących i sprawujących władzę w zupełnie innym okresie historycznym należy tłumaczyć względami propagandowymi. O ile bowiem - jak na to wskazuje insygnium władzy książęcej w postaci mitry - Witekind (Widukind) miał władzę ograniczona do terytorium saskiego, o tyle August II posiadający koronę clausa cieszył się szacunkiem poddanych zarówno jako elektor saski, jak i król polski. Dziedzictwo zapoczątkowane przez Witekinda (Widukinda) znalazło więc godnego kontynuatora w osobie Augusta II Wettyna.

W zbiorach Narodowej Biblioteki Austriackiej przechowywany jest datowany na XVIII stulecie i niesygnowany portret Witekinda (Widukinda) ${ }^{31}$ przypominający częściowo wizerunek medalierski na rewersie medalu. Władca Sasów odziany jest również w szatę spodnią $z$ długimi bufiastymi rękawami, przewiązana na wysokości pasa sznurem, oraz płaszcz $z$ wyszytymi sześcioramiennymi gwiazdami, spięty pod szyją kolista brosza i urozmaicony pionowymi pasami na obrzeżeniu $z$ przyszytymi owalnymi i okragłymi kamieniami szlachetnymi. Głowę portretowanego nobilituje także mitra ksiażęca o wyglądzie zbliżonym do jej odpowiednika znanego $z$ medalu. Oprócz mitry do insygniów władzy należy zaliczyć berło dzierżone $\mathrm{w}$ prawym ręku schowanym pod płaszczem Witekinda (Widukinda). Gest czyniony przez portretowanego poprzez skrzyżowanie palca wskazującego i środkowego lewej ręki należy odczytywać jako złożenie przysięgi, ślubowania lub obietnicy. Napis poniżej dostarcza informacji o rzekomej tytulaturze Witekinda (Widukinda).

Kolejny medal, datowany na 1697 r. i sygnowany na awersie: C. W. (Christian Wermuth?), zaprojektowano $z$ myśla o wykazaniu, że przodkiem aktualnego władcy polskiego Augusta II był Kazimierz IV Jagiellończyk ${ }^{32}$. Tym samym więc, zgodnie $z$ założeniami

31 Wiedeń, Narodowa Biblioteka Austriacka, nr inw. 00054931_01.

32 Własność prywatna. Przedmiot wystawiony na aukcji „Gabinet Numizmatyczny Damian Marciniak” (Gdańsk) 10 II 2018 r. (aukcja 4, kat. nr 1360), E. Raczyński, op. cit., t. II, poz. 269. 
propagandzistów królewskich, pierwszego Wettyna na tronie polskim królewscy poddani powinni uważać za spadkobiercę i kontynuatora dynastii Jagiellonów. Postać monarchy została utrwalona na awersie w prawym profilu. Oprócz zbroi płytowej $z$ widocznym fragmentem naramiennika folgowego przytwierdzonego do kirysu za pomocą gwoździ elementami królewskiej kreacji są także narzucony na lewe ramię płaszcz podbity gronostajem i peruka à la lion. Napis w otoku: FRIDERICUS AUGUSTUS DEI GRATIA REX POLONIAE SACRI ROMANI IMPERII ARCHIMARESCHALLUS ET ELECTOR (Fryderyk $z$ Bożej łaski król polski, świętego rzymskiego państwa arcymarszałek i elektor) przypomina o tytulaturze panującego.

Znana jest rycina (miedzioryt, papier żeberkowy) autorstwa Pietera Schenka datowana na koniec XVII w. ${ }^{33}$ Postać Augusta II Wettyna artysta przybliżył w ujęciu en trois quarts z głowa odwróconą w prawą stronę. Monarcha ma na sobie koszulę spodnią wraz $z$ koronkowym żabotem pod szyja, zbroję $z$ naramiennikiem folgowym, którego poszczególne folgi połączono za pomoca gwoździ oraz płaszcz podbity gronostajem narzucony na lewe ramię. Na rycinie nie zabrakło również najbardziej charakterystycznego elementu kreacji królewskiej - peruki à la lion z puklami sztucznych włosów. W głębi po prawej stronie na postumencie (?) lub kwadratowym stoliku (?) leżą regalia: korona clausa oraz skrzyżowane berło i miecz. Mimo istnienia wyraźnych podobieństw między rycina a medalem nie sposób stwierdzić, czy medalier przed realizacją zamówienia miał kontakt $z$ grafiką. Do tych samych rozwiązań zastosowanych na kompozycji tak graficznej jak i medalierskiej należy zaliczyć sposób prezentacji fragmentu naramiennika folgowego królewskiej zbroi Augusta II. Natomiast udrapowanie i ułożenie poszczególnych fałd płaszcza podbitego gronostajem na rycinie nie znajduje odzwierciedlenia na awersie medalu. Na medalierskim wizerunku Augusta II brakuje również tak charakterystycznego dodatku do koszuli jak koronkowy żabot wyeksponowany na portrecie graficznym.

Rewers medalu sygnowanego C. W. z 1697 r. wypełniaja z kolei napisy pamiattkowe: ELECTUS D[ie] 17/27 JUNIO CORONATUS D[ie] 5/15 SEPT[embris] 1697 (Obrany dnia 17/27 czerwca, koronowany dnia 5/15 września 1697) (w kartuszu z dwóch ga-

${ }^{33}$ Warszawa, Muzeum Narodowe, nr inw. 62011, E. Łomnicka-Żakows ka, Graficzne portrety..., s. 60, poz. 13. 
łazek palmowych w centrum kompozycji), POLONIS SANGVINE IUNCTUS (Z Polakami krwią, połączony) (w odcinku u góry) oraz wzmiankowane drzewo genealogiczne $z$ inskrypcjami dotyczacymi Augusta II i jego przodków połączonymi wicia drzewa wawrzynu: FRID AVGVST REX POL EL SX/ IOHANN GEORG III EL SAX/ IOH GEORG II EL SAX/ MAGD SIBYLL CONI I G I E S/ MAGD SIBYL CONI I G I E S/ CHRISTI MARCH BRAND/ IOANN GEORG EL BR/ ALBERT FRID DVX BORVS/ MAGDAL CON IOAG II EL BR/ SOPHIA CONI FR MAR FR/ BARBARA CON GEOR DVC SAC/ COSIMIR IV REX POL. Wymienione inskrypcje sporządzono w owalnych kartuszach przykrytych mitrami książęcymi. Jedynie kartusze $z$ tytulatura królewska Augusta II Wettyna (u góry) i Kazimierza IV Jagiellończyka (u dołu) zwieńczone są koronami clausa.

Medalierzy tworzacy medale dla Augusta II Wettyna dbali również o odpowiednie wyeksponowanie symboliki heraldycznej. Przykładem tych starań jest niesygnowany medal z $1697 \mathrm{r}^{34} \mathrm{Na}$ awersie medalier wykonał popiersie królewskie w prawym profilu będące wypadkową wzorców antycznych i nowożytnych. O ile bowiem wieniec laurowy nobilitujący skronie królewskie i udrapowanie płaszcza królewskiego $z$ brosza na lewym ramieniu moga sugerować oglądającemu związki z ikonografią starożytnych Rzymian, o tyle sama zbroja jest jak najbardziej współczesna modelowi. Ubiór monarszy składa się $z$ cyzelowanego kirysu, naramiennika folgowanego oraz wymienionych płaszcza podbitego futrem i wieńca laurowego (na głowie). Inskrypcja otokowa: AUGUSTUS II D[ei] G[ratia] REX POLON[iae] ET M[agnus] D[ux] Li[thuaniae] (August II $z$ Bożej łaski król polski, wielki książę litewski) przypomina o oficjalnej królewskiej tytulaturze.

Natomiast rewers podporządkowany został w całości propagowaniu herbów Korony i Litwy oraz dynastii Wettynów. Zajmujący większą część rewersu okrągy, barokowy kartusz przykryty koroną clausa, ujęty pomiędzy dwoma gałązkami palmowymi i ozdobiony wolutowymi spływami zawiera wyobrażenia podwójne: Orła Piastowskiego i Pogoni Litewskiej oraz pojedyncze: mieczy elektorskich i herbu rucianego Wettynów wpisane w wymienione znaki heraldyczne Rzeczpospolitej Obojga Narodów. Napis w dwóch otokowych wierszach: SAC[ri] ROM[ani] IMP[erii] ARCHIM[arescalus] ET ELECT[or] SAXON[iae] ELECT[us] D[ie] 27 IUN[ii] CORONAT[us] 15 SEPT[embris] ANNO 1697 (Świętego Państwa Rzymskiego

${ }^{34}$ E. Raczyński, op. cit., t. II, por. 273. 
arcymarszałek i elektor saski obrany dnia 27 czerwca, koronowany dnia 15 września roku 1697) nawiązuje do dwóch minionych wydarzeń - królewskiej elekcji pod Warszawą i koronacji na Wawelu w Krakowie.

Kolejny medal z 1697 r. sygnowany u dołu awersu i rewersu: I. R. E. bez watpienia inspirowany był emblematyka ${ }^{35}$. Na awersie pracy dostrzec można realistyczny wizerunek młodego Augusta II w narzuconym na ramiona płaszczu oraz we współczesnej zbroi $z$ widocznym jedynie naramiennikiem folgowym. Podobizna władcy została utrwalona w prawym profilu. Napis otokowy: FRID[ericus] AUG[ustus] SAXO REX POLO[niae] CORO[natus] 5/15 SEP[tembris] 1697 (Fryderyk August Sas król polski, koronowany dnia 5/15 września 1697) przypomina oglądającemu o uroczystościach sakry królewskiej w Krakowie, w katedrze na Wawelu.

Spośród zachowanych wizerunków Augusta II powstałych ad vivum należy wyróżnić jeden ze względu na ubiór królewski i szczegóły anatomiczne monarchy, zbliżony do kompozycji awersu medalu. Mowa o obrazie (papier, pędzel i sepia) będącym kopią rysunku, autorstwa Feitamy Sybranda, datowanym na XVIII w. ${ }^{36}$ Popiersie królewskie, które stanowi przedmiot naszego zainteresowania, zostało ujęte $\mathrm{w}$ owalna ramę podtrzymywana przez personifikację Fortuny - skrzydlata niewiastę $z$ rozwichrzonymi włosami, odzianą w materię okrywająca jedynie intymne części ciała, w prawym ręku trzymającą berło $z$ orłem na szczycie, w lewym ręku zaś klepsydrę zwieńczoną koroną clausa, u stóp której leży róg obfitości z owocami oraz pozostałe insygnia królewskie - korona aperta i drugie berło. Po prawej stronie, obok medalionu królewskiego, spoczywa ponadto na poduszce $z$ frędzlami mitra książęca $z$ krzyżem. August II wewnątrz medalionu został uwieczniony w ujęciu en trois quarts $z$ głową skierowana $\mathrm{w}$ prawo. Analizując królewskie odzienie, trzeba wymienić marszczona koszulę, stalowy kirys $z$ naramiennikiem folgowym, w końcu płaszcz podbity gronostajem, narzucony na ramiona i perukę à la lion. Oczywiście największa różnica dotyczy przyjętego i zaaprobowanego przez dysponenta sposobu uwieczniania postaci panującego. Awers medalu wypełnia podobizna królewska w prawym profilu. Natomiast na obrazie władca zwrócony jest niemal na wprost oglądającego. Ponadto nie

${ }^{35}$ Ibidem, poz. 274.

${ }^{36}$ Warszawa, Muzeum Narodowe, nr inw. 62090, E. Łomnicka-Żakows ka, Graficzne portrety..., s. 88, poz. 27. 
powinno dziwić to, że lokalizacja odsłoniętego królewskiego naramiennika folgowego jest w przypadku obydwu opisywanych dzieł sztuki odmienna. Medal stanowi bowiem lustrzane odbicie obrazu. To jedynie potwierdza tezę o związkach między obrazem a medalem. Również udrapowanie i ułożenie płaszcza królewskiego oraz modelowanie kirysu sa tak na kompozycji malarskiej, jak i medalierskiej zbliżone.

Rewers medalu sygnowanego I. R. E. z 1697 r. natomiast stanowi odzwierciedlenie, być może zmodyfikowane przez samego artystę medaliera niezidentyfikowanego wyobrażenia emblematycznego. W centrum kompozycji znajduje się drzewo palmowe, na wierzchołku którego zlokalizowany jest w pozycji pionowej kamień młyński. Wokół drzewa wije się wąż, na którego czatować zdaje się utrwalony w nieco większej odległości smok. Ponadto w oddali rosna jeszcze trzy inne drzewa. Sporządzony w górnym półkolu krażka napis: NEC PONDERE FRANGOR (Ani mię ciężar nie złamie) sugeruje oglądającemu, że kompozycja artystyczna drugiej strony medalu dotyczy bezpośrednio samego Augusta II Wettyna.

$\mathrm{Na}$ pogłębiona analizę $\mathrm{w}$ konfrontacji $\mathrm{z}$ opisanym numizmatem zasługuje dzieło sztuki medalierskiej dedykowane Don Matthiasowi Habsburgowi zaprojektowane przez Alessandra Abondia na początku XVII w. ${ }^{37}$ Kluczowe dla naszych rozważań wyobrażenie powalonej palmy, której kłodzina (pień) obciążona jest przez głaz, artysta uwiecznił na rewersie. Zarówno korona drzewa, jak i jego korzeń spoczywaja oparte o dwa kolejne głazy. Napis otokowy: PREMOR SED NON OPPRIMOR należy odczytywać jako komentarz do kompozycji medalierskiej. Tematyka pracy Abondia zbliżona jest do przesłania wzmiankowanego medalu $z$ około 1697 r. Drzewo palmowe w obydwu przypadkach należy oczywiście utożsamiać z majestatem władcy. Mimo wielu przeszkód symbolizowanych przez głazy narzutowe obciążające koronę (w przypadku medalu z 1697 r.) oraz kłodzinę (w przypadku medalu z początku XVII w.) drzewo palmowe nie ulega złamaniu czy wyschnięciu.

Słuszne więc pozostaje pytanie o celowość tego typu zabiegów artystycznych. Zgodnie $z$ pogladami Arystotelesa i Plutarcha palma miała wyróżniać się niezwykłymi cechami ${ }^{38}$ : gałęzie i kłodzina wspomnianego drzewa nawet nadmiernie obciążone nie ulegają złamaniu, a po odjęciu ciężaru $z$ powrotem się wyprostowują.

${ }^{37}$ M. Stahr, Medale Wazów..., s. 150.

38 Ibidem, s. 150-151. 
Przechodząc zaś do czasów nowożytnych, warto przypomnieć, że zgodnie $z$ myśla XVII-wiecznych teoretyków sztuki palma obrazowała niezłomna cnotę oraz triumf moralności ${ }^{39}$.

Warto w tym miejscu odnieść się także do spuścizny medalierskiej polskich Wazów, gdyż jeden $z$ żetonów, emitowany $z$ polecenia małżonki Władysława IV Wazy i Jana II Kazimierza - Ludwiki Marii Gonzagi, mimo że $z$ cała pewnościa nie stanowił podstawy dla medaliera działającego dla dworu Wettynów, reprezentuje jednak podobną tematykę. Mowa w tym miejscu o żetonie koronacyjnym $z 1646$ r., autorstwa anonimowego medaliera ${ }^{40}$. Podobnie jak w przypadku rewersu interesujacego nas numizmatu z 1697 r., także na drugiej stronie żetonu wazowskiego widnieje palma. W tym przypadku jednak cztery kamienie (nie jeden kamień!) ja obciążające nie leżą na jej koronie, nad którą unosi się najważniejsze insygnium królewskie - korona clausa, lecz sa przymocowane do jednej $z$ jej gałęzi (po lewej stronie). Inskrypcja komentujacca: HAC SVFFVLTA RESVRGO (Na tym wsparta powstaję) wskazuje, że elementem, dzięki któremu palma (królowa) powstaje, jest paradoksalnie właśnie korona.

Następny medal, mimo że jego rewers stanowi w zasadzie powtórzenie jednego $z$ poprzednio opisywanych medali, to już awers reprezentuje zupełnie inne treści. Numizmat zrealizowany przez anonimowego medaliera pochodzi $z \quad 1697 \mathrm{r} .{ }^{41} \mathrm{~W}$ naszych rozwa-

${ }^{39}$ G. Tervarent, Attributs et symboles dans l'art profane 1450-1600: dictionnaire d'un langage perdu, Geneve 1959, s. 295; E. Chojecka, Dekoracja malarska ksiag promotionum i diligentiarum Uniwersytetu Jagiellońskiego XVI-XVII wieku, Kraków 1965, s. 59.

40 Poznań, Muzeum Narodowe, nr inw. MNP GN E 860; J.D. Köhler, Der wöchentlichen historischen Münz-Belustigung... Stück: darinnen allerhand merckwürdige und rare Thaler, Ducaten, Schaustücken, andere sonderbahre Gold- und Silber-Münzen: nebst einer Vorredevon Joh. Luckii Sylloge Numismatu, t. VII, Nürnberg 1740, poz. 30/26; J. Albertrandy, Album rycin medali $i$ monet $z$ płyt przygotowanych do dzieła $x$. Biskupa Jana Albertrandego w latach 1822-1828 znajdujacych sie obecnie $w$ Akademii Sztuk $w$ Petersburgu, [b.m. i d.w.], rkps 44, s. 4; i d em, Historya polska ostatnich trzech wieków medalami zaświadczona i objaśniona, rękopism około 200 w polskim języku skreślony, a częścia i po francuzku napisany, znajdował sie $w$ bibliotece $b$. Warszawskiego Towarzystwa przyjaciót nauk, [b.m. i d.w.], s. 87; E. Raczyński, op. cit., t. I, poz. 124; E. Hutten-Czapski, op. cit., t. I, poz. 1861; M. Gu mows ki, Medale Władysława IV, „Wiadomości Numizmatyczno-Archeologiczne" 1939, t. XX, s. 102; M. Stahr, Medale Wazów..., s. 150-151, kat. nr 58; idem, Medale polskie..., s. 65, poz. 52, 53 (odmiana).

${ }^{41}$ E. Raczyński, op. cit., t. II, poz. 275. 
żaniach skupimy się jedynie na jego pierwszej stronie. W środku kompozycji oglądający zauważy rękę wyłaniająca się z obłoków i ochraniana przez nałokcic, karwasz i rękawicę ściskająca pałasz. Dzięki konfrontacji z żetonem pochodzacym $z$ pierwszych lat panowania Jana III Sobieskiego utwierdzamy się w przekonaniu, że także w tym przypadku istnieja pewne analogie. Z 1676 r. pochodzi żeton autorstwa anonimowego medaliera, którego rewers wypełnia wyobrażenie ręki Opatrzności (manus Dei) dzierżącej miecz sprawiedliwości, przez który przewieszone są trzy wieńce: laurowy, dębowy i oliwny ${ }^{42}$. W przypadku medalu przypisywanego Augustowi II mamy więc do czynienia $z$ uproszczona wersja tego samego numizmatu. Bez watpienia nowy władca elekcyjny, pochodzacy z Saksonii, niejednokrotnie starał się odwoływać do przekazu propagandowego znanego doskonale $z$ czasów Sobieskiego. Augustowi II zależało bowiem na wykazaniu, że jest godnym sukcesorem zwycięzcy spod Chocimia i Wiednia, którego scheda miała początkowo przypaść jednemu $z$ jego synów.

Kolejny medal stanowi w zasadzie twórcza interpretację przydomku Augusta II, którego ze względu bardzo dużą siłę obwołano jeszcze za życia Herkulesem Saskim. Numizmat także datowany jest na $1697 \mathrm{r}^{43}$ Znamy również sygnaturę jego twórcy umieszczona na awersie pod ramieniem królewskim: I. N. Podobnie jak na innych medalach awers poświęcono na prezentację sylwetki monarchy. August II ma na sobie oprócz charakterystycznej peruki à la lion również koszulę $z$ marszczonym kołnierzem, kirys $z$ naramiennikiem folgowym i napierśnikiem, przepasany wstęga orderowa oraz płaszcz podbity gronostajem, spięty pod szyją zaponą. Także

${ }^{42}$ Warszawa, Muzeum Narodowe, nr inw. 16393 MNW; Kraków, Muzeum Narodowe, Zbiory Czartoryskich, nr inw. Cz. 1415; Własność prywatna. Przedmiot wystawiony na aukcji antykwariatu „Fritz Rudolf Künker GmbH \& Co. KG” (Osnabrück) 13 III 2012 r. (aukcja nr 206, kat. nr 3232); F. Bentkowski, Spis medalów polskich lub $z$ dziejami krainy polskiej stycznych, w gabinecie Król. Alex. Uniwersytetu $w$ Warszawie znajdujacych się, tudzież ze zbiorów i pism rozmaitych lub podan zebrany i porzadkiem lat ułożony, Warszawa 1830, poz. 212, 213; E. Raczyński, op. cit., t. I, poz. 195; E. Hutten-Czapski, op. cit., t. I, poz. 2415; W. Bartynowski, op. cit., poz. I.G. 18257, I.G. 18258, I.G. 18260 (odmiany); C. Kamiński, W. Kowalczyk, op. cit., s. 121-136, poz. 63; Kolekcja generała Jerzego Węsierskiego..., poz. 2566; Zbiory Poznańskiego Towarzystwa Przyjaciót Nauk $w$ Muzeum Narodowym w Poznaniu. Katalog wystawy, red. Z. Białłowicz-Krygierowa, M. Warkoczewska, Poznań 1982, s. 117, poz. 208, 209; Chwała i stawa Jana III..., s. 209-210, kat. nr 176.

${ }^{43}$ E. Raczyński, op. cit., t. II, poz. 276. 
Jana III Sobieskiego portretowano w podobnym płaszczu. Wymienić należy chociażby awers medalu z 1683 r., autorstwa Jochanna Smeltzinga (Schmelzingera) ${ }^{44}$. Co prawda opisywany płaszcz gronostajowy narzucony został na królewski żupan z pętlicami i guzami, nie zaś na stalową zbroję, lecz ma zbliżony krój i wykończenie. Także na awersie medalu Smeltzinga (Schmelzingera) na przestrzeni między fragmentami futra gronostajowego wyszyto ornament roślinny. Napisy w otoku i u dołu w odcinku: FRIDERICVS AVGVSTVS SAXO REX POLONORVM (Fryderyk August Sas, król Polski) oraz CORONAT[us] 5/15 SEPTEMB[ris] (koronowany dnia 5/ 15 września) zawierają tytulaturę królewską i podstawowe informacje o koronacji.

Również w tym przypadku udało mi się odnaleźć późniejszą rycinę (miedzioryt, papier, częściowo punktowany) nawiązująca do wyglądu pierwszej strony medalu. Autorem pracy, datowanej na około 1700 r., pozostaje anonimowy rytownik ${ }^{45}$. Zdecydował się on przedstawić monarchę $\mathrm{w}$ ujęciu en trois quarts, $\mathrm{z}$ głowa skierowana $\mathrm{w}$ prawo. August II ma na sobie koszulę spodnią $z$ marszczonym kołnierzem, kompletna zbroję: stalowy kirys ozdobiony gwiazda orderowa, przepasany wstęga orderowa wraz $z$ naramiennikiem folgowym i tarczka podbita od spodu materia, futrzany płaszcz spięty pod szyja podłużna zaponą oraz perukę à la lion (na głowie). Wśród elementów występujących na rycinie oraz na medalu należy

${ }^{44}$ Kraków, Muzeum Narodowe (zbiory E. Hutten-Czapskiego), nr inw. VII-Md-622; Warszawa, Muzeum Narodowe, nr inw. 11774 MNW; Biblioteka Narodowa, Zakład Zbiorów Ikonograficznych, nr inw. I.G. 18311; Własność prywatna. Przedmiot wystawiony na aukcji antykwariatu „Dr. Busso Peus Nachfolger” (Frankfurt nad Menem) 4 XI 2009 r. (aukcja nr 399, kat. nr 872); G. L o o n, Beschryving der Nederlandsche Historiepenningen, Bd. IV, Graavenhaage (Haga), München 1723; E. Raczyński, op. cit., t. I, poz. 221; E. Hutten-Czapski, op. cit., t. I, poz. 2521; W. Bartynowski, op. cit., poz. I.G. 18311, I.G. 18312; S. Chelminski, Sammlung des Herrn Sigismund von Chelminski, Szarawka (Russland). Münzen und Medaillen von Polen und sonstige auf Polen bezügliche Gepräge: die öffentliche Auction findet statt: Montag, den 25 April 1904 und folgende Tage, hrsg. S. von Chelminski, O. Helbing, München 1904; U. Thi e me, F. Becker, Allgemeines Lexikon der bildenden Künstler von der Antike bis zur Gegenwart [...], t. XXI, Leipzig 1927, s. 154; J. Manthey, op. cit., s. 19-20; C. Kamiński, W. Kowalczyk, op. cit., s. 121136, poz. 67; J. Strzałkow ski, Słownik medalierów polskich i z Polska zwiazanych (1508-1965), Warszawa 1982, s. 108; Chwała i sława Jana III..., s. 216-217, kat. nr 193; Odsiecz wiedeńska..., t. I, s. 247, kat. nr 397. Sygnatura zawierająca inicjały autora medalu: I.S. znajduje się w dolnej części awersu w otoku.

${ }_{45}$ Warszawa, Muzeum Narodowe, nr inw. 62186, E. Ło mnicka-Żakows ka, Graficzne portrety..., s. 62, poz. 14. 
wyróżnić: kirys, naramiennik folgowy, wstęgę orderową (na awersie medalu jednak węższą niż na rycinie), futrzany płaszcz spięty pod szyja zapona i perukę à la lion. Najważniejsze różnice dotyczą wyglądu wspomnianej tarczki naramiennika (na awersie medalu mającej zaokraglone, na rycinie zaś proste brzegi). Medalier również nie odwzorował na pierwszej stronie medalu występującej na kirysie (na rycinie) gwiazdy orderowej oraz zawiasu łączącego dwie części kirysu.

Rewers medalu sygnowanego I. N. z 1697 r. zaprojektowano natomiast, bazujacc na tematyce mitologicznej, zmodyfikowanej i przetworzonej jednak zgodnie $z$ oczekiwaniami saskiego dysponenta. Usytuowanego centralnie Herkulesa dzierżącego w prawym ręku maczugę, w lewym zaś koronę okrywa jedynie skóra $z$ lwa nemejskiego $z$ pyskiem na głowie ( $z$ przednimi łapami związanymi ze soba pod szyja). Obok postaci Herkulesa wzniesiono kwadratowy zapewne kamienny postument ozdobiony gzymsem i płycinami, na którym spoczywają dwa skrzyżowane miecze elektorskie będące artystyczną trawestacją herbu elektorów saskich. Napisy w otoku i u dołu: HANC MIHI ADIMET NEMO (Tej mi nikt nie odbierze) HERCULES SAXONICUS (Herkules saski) odnoszą się bezpośrednio do głównego bohatera kompozycji. Bez względu na istniejące tradycje przydomku Augusta II warto wskazać na występujące w ikonografii motywy związane $z$ Herkulesem. Okazuje się, $\dot{z}$ e również wazowski poprzednik pierwszego Sasa na tronie polskim - Władysław IV Waza celowo godził się na utożsamianie własnej osoby z mitycznym bohaterem. Wymienić należy medal autorstwa Jana Höhna (Hoehna) st. z 1637 r., wybity z inicjatywy dysponenta gdańskiego na pamiątkę zaślubin Władysława IV z Cecylią Renata $^{46}$. W tym przypadku nawiazanie do przekazu mitologicznego pozostaje bardziej wyraźne. Herkules Polski (Władysław IV Waza)

${ }^{46}$ Warszawa, Muzeum Narodowe, nr inw. 16207 NPO; Własność prywatna. Przedmiot wystawiony na aukcji WCN 18 XI 1995 r. (aukcja stacjonarna nr 10, kat. nr 10/845); J. Albertrandy, Album rycin medali i monet..., rkps 41, s. 3, 73; E. Raczyński, op. cit., t. I, poz. 109, 117; E. Hutten-Czapski, op. cit., t. I, poz. 1775, 1777; E. Bahrfeld t, Die Münzen und Medaillen Sammlung in der Marienburg, Bd. I-VI, Danzing-Königsberg 1910, poz. 8686, 8687; M. Gu mow ski, Medale Władysława IV..., s. 58, 60; M. Stahr, Medale Wazów..., s. 134-135, kat. nr 49, 50; J. Dutkowski, Corpus Nummorum Gedanensis. Katalog i cennik monet, medali i żetonów gdańskich i z Gdańskiem zwiazanych 1200-1998, Gdańsk 2000, s. 226, poz. 559, 560 (egzemplarze złote); M. Stahr, Medale polskie..., s. 60, poz. 47; J. Dutkowski, Złoto czasów dynastii Wazów, Gdańsk 2015, s. 482-484, poz. 306, 307 (egzemplarze złote). 
- nagi mężczyzna w skórze lwa nemejskiego na prawym ramieniu i materii chroniącej części intymne części ciała walczy bowiem za pomoca maczugi (w lewym ręku) $z$ trzygłowym psem Cerberem (Państwem Moskiewskim, Imperium Tureckim i Królestwem Szwecji) na tle twierdzy Smoleńsk $z$ kwadratowa jednoprzelotowa wieżą bramna $z$ blankami na szczycie oraz budynkiem $z$ kopułą i kościołem $z$ sygnaturką (wewnątrz murów). Analogie do odblokowania Smoleńska, oblężonego przez wojska moskiewskie Michał Borysowicza Szeina w wyniku bitwy trwajacej 7 września 1633 do 24 lutego 1634 r. przez Władysława IV, sa w tym przypadku oczywiste. Nie ulega więc wątpliwości, że polski odbiorca medali pochodzącego z Saksonii władcy Rzeczypospolitej potrafił bez większych problemów odczytać przesłanie dzieła. Funkcja napisu w otoku i w odcinku: VLADISLAO IV POLONIAE ET SVECIAE REGI HERCULI PACIFICO CIVIT[as] GEDAN[ensis] F[ieri] F[ecit] jest w zasadzie identyczna jak w przypadku numizmatu z $1697 \mathrm{r}$.

Kolejny medal $z$ wykonana na awersie (pod ramieniem królewskim) sygnaturą: G. W., wyemitowany około 1697 r., także pod względem zastosowanych na awersie elementów kompozycji nawiazuje do ikonografii medali Jana III Sobieskiego ${ }^{47}$. Na pierwszej stronie medalu uwzględniono portret Augusta II w prawym profilu, będący po części odbiciem reprezentacyjnych portretów $z$ okresu cesarstwa rzymskiego. Ubiór panującego składa się z koszuli $z$ marszczonym kołnierzem, kirysa $z$ naramiennikiem folgowym oraz płaszcza spiętego na wysokości lewego ramienia okragła broszą. Najważniejszym jednak elementem kreacji królewskiej przywodzącymi na myśl wzorce rzymskie jest wieniec laurowy wieńczący skronie portretowanego. Istnieje szereg medalierskich przedstawień Jana III Sobieskiego w wieńcach laurowych. Należy wspomnieć o awersach następujących numizmatów koronacyjnych: dwóch niesygnowanych żetonów koronacyjnych z 1676 r. ${ }^{48}$, medalu, autorstwa Jana Höhna (Hoehna) mł. z 1676 r..$^{49}$, medalu

47 E. Raczyński, op. cit., t. II, poz. 278.

48 Warszawa, Muzeum Narodowe, nr inw. 16393 MNW; Kraków, Muzeum Narodowe, Zbiory Czartoryskich, nr inw. Cz. 1415; Własność prywatna. Przedmiot wystawiony na aukcji antykwariatu „Fritz Rudolf Künker GmbH \& Co. KG” (Osnabrück) 13 III 2012 r. (aukcja nr 206, kat. nr 3232).

${ }^{49}$ Kraków, Muzeum Narodowe (zbiory E. Hutten-Czapskiego), nr inw. VII-Md-460; Toruń, Muzeum Okręgowe, nr inw. 50; Warszawa, Muzeum Narodowe, nr inw. 16395 NPO; Własność prywatna. Przedmiot wystawiony na aukcji antykwariatu „Coin Galleries Sale” (Oyster Bay) 21 X 2010 r. (kat. nr 3187). 
o wartości donatywy cztero- i półdukatowej, autorstwa Jana Höhna (Hoehna) ml. z 1676 r. ${ }^{50}$, niesygnowanego medalu z 1676 r. ${ }^{51}$, medalu autorstwa Jana Höhna (Hoehna) mł. $z$ około 1676 r. ${ }^{52}$ Inskrypcja otokowa medalu $z$ około 1697 r.: AUG[ustus] II D[ei] G[ratia] REX POL[oniae] M[agnus] D[ux] L[ithuaniae] D[ux] SAX[oniae] S[acri] R[omani] I[mperii] AM[arebimarschalcus] ET EL[ector] (August II z Bożej łaski król polski wielki książę litewski, książę saski, świętego państwa rzymskiego arcymarszałek elektor) zawiera tytulaturę władcy.

Rewers medalu stanowi artystyczną ilustrację aktu sakry królewskiej Augusta II dokonanego w katedrze wawelskiej. Lecacy $z$ góry $\mathrm{w}$ kierunku ziemi (pokrytej częściowo roślinnościa) orzeł (piastowski) dzierży w dziobie koronę clausa, w szponach zaś królewskie berło. Napisy: w otoku w górnej części: DIGNISSIMO (Najgodniejszemu) i w dolnej części w odcinku: CORONAT[us] CRACOV[iae] D[ie] 15 SEPT[embris] MDCIIIC (Koronowany w Krakowie dnia 15 września 1697 r.) nie pozostawiają wątpliwości co do tego, czyjej osoby dotyczy główne przesłanie rewersu. Należy zauważyć, że już w czasach Sobieskiego w podobny sposób dworscy artyści wyrażali królewskie przymioty. Mowa o obrazie autorstwa nieznanego bliżej malarza polskiego, datowanym na przełom XVII i XVIII w. i poświęconym gloryfikacji Jana III Sobieskiego. ${ }^{53}$ Powyżej konnego portretu Jana III Sobieskiego na tle anonimowych zmagań wojennych zidentyfikować można orła (piastowskiego) ściskającego w szponach nie koronę clausa, lecz regiment i buławę hetmańska. Wspomniany ptak $z$ regimentem (w prawych szponach) i buława hetmańska (w lewych szponach) przypominał oglądającemu o kompetencjach wojskowych władcy, którego podobizna na wspiętym koniu $z$ barokowym kartuszem na przodzie, w delii $z$ szerokim kołnierzem i żupanie $z$ przypiętą do pasu pochwą na rapciach), wyróżniona padającymi z góry promieniami słonecz-

${ }^{50}$ Kraków, Muzeum Narodowe (zbiory E. Hutten-Czapskiego), nr inw. MNK VII-Md-637; Warszawa, Muzeum Narodowe, nr inw. 16482 NPO.

${ }^{51}$ Kraków, Muzeum Narodowe (zbiory E. Hutten-Czapskiego), nr inw. VII-Md-422; Warszawa, Muzeum Narodowe, nr inw. 4288; F. Ben tkow ski, op. cit., poz. 209, 210; Wrocław, Zakład Narodowy im. Ossolińskich, nr inw. G 1588.

${ }^{52}$ Kraków, Muzeum Narodowe (zbiory E. Hutten-Czapskiego), nr inw. VII-Md-433; Własność prywatna. Przedmiot wystawiony na aukcji WCN 27 II 2016 r. (aukcja nr 63, kat. nr 813).

${ }^{53}$ Warszawa, Muzeum Pałac w Wilanowie, nr inw. Wil. 3790; Chwała $i$ sława Jana III..., s. 276, kat. nr 334. 
nymi, została odtworzona poniżej. W lewym ręku Sobieskiego spoczywa wyciągnięta szabla, w prawym zaś dzierży cugle. Malarz uwiecznił władcę w całej postaci, $z$ głową odwróconą en trois quarts w prawo. Także badajac medale pozostałe po Janie III Sobieskim, można odnaleźć dzieło medalierskie z 1676 r. ${ }^{54}$, na którego rewersie widnieje wyobrażenie orła (piastowskiego) wzlatującego (nie zaś zstępującego $z$ nieba) ku słońcu oznaczającemu majestat królewski. Co prawda w szponach zwierzęcia znajduje się jedynie tarcza Sobieskich Janina, to jednak głowę najszlachetniejszego $z$ ptaków ozdabia królewska korona clausa.

Kolejny niesygnowany medal $z$ około 1697 r., podobnie jak jedno $z$ poprzednio opisanych dzieł, został zaprojektowany $z$ wykorzystaniem treści emblematycznych ${ }^{55}$. Awers pracy, podobnie jak w przypadku innych dzieł, poświęcono prezentacji sylwetki aktualnego władcy. Również w tym przypadku można wyodrębnić charakterystyczne elementy XVIII-wiecznego ubioru, takie jak kirys $z$ widocznym naramiennikiem folgowym i udrapowany na wysokości klatki piersiowej płaszcz, spięty na lewym ramieniu okragła broszą. Z tytulatura królewską Augusta II można się zapoznać, czytając napis otokowy: FRID[ericus] AUG[ustus] D[ei] G[ratia] REX POLON[iae] (Fryderyk August z Bożej łaski król Polski).

Interesujacy pozostaje rewers medalu zdradzający ideowe podobieństwo do drugiej strony poprzednio opisywanego medalu. Identyczne są w każdym razie napisy w otoku w górnej części: DIGNISSIMO (Najgodniejszemu) i w dolnej części w odcinku: CORONAT[us] CRACOV[iae] D[ie] 15 SEPT[embris] MDCIIIC (Koronowany w Krakowie dnia 15 września 1697). W centrum rewersu artysta utrwalił okragły stół o jednej nodze, nakryty nieznana materia zakończona frędzlami. Na stole leżą obok siebie: korona clausa i królewskie berło.

Także w tym przypadku historyk sztuki badający ewentualne źródła inspiracji dla twórcy czynnego na dworze saskim musi odwołać się do programu nigdy nieukończonego dzieła sztuki $z$ epoki Sobieskiego. Zapewne na krótko przed elekcją tego władcy (21 maja 1674 r.) Gotfryd Peschewitz - kupiec gdański, a zarazem znawca emblematów, planował na własny koszt emisję medalu

${ }^{54}$ Kraków, Muzeum Narodowe (zbiory E. Hutten-Czapskiego), nr inw. VII-Md-422; Warszawa, Muzeum Narodowe, nr inw. 4288; F. B en tkow ski, op. cit., poz. 209, 210; Wrocław, Zakład Narodowy im. Ossolińskich, nr inw. G 1588.

55 E. Raczyński, op. cit., t. II, poz. 279. 
pamiątkowego będącego dowodem jego przywiązania i szacunku dla władcy. To właśnie na polecenie Peschewitza Henryk Duven sporządził, posługując się jedynie tuszem, rysunek interesującego nas numizmatu ${ }^{56}$. Dwa najważniejsze elementy kompozycji, tj. okragły stół nakryty kobiercem $z$ frędzlami oraz korona królewska clausa, wykazuja podobieństwo do ich odpowiedników na drugiej stronie medalu z 1697 r. Natomiast odwrócona, okrągła tarczę spoczywająca na stole i będacca zarazem rodzajem postumentu dla wzmiankowanego najważniejszego insygnium koronacyjnego należy interpretować w związku $z$ osoba, której dedykowany miał być medal. Jan III Sobieski niejednokrotnie kazał nadwornym artystom swój własny znak rodowy upamiętniać za pośrednictwem różnego rodzaju dzieł sztuki. Kolejne elementy kompozycji, czyli chmury przesłaniające niebo, przez które przenikaja płomienie słońca, zabudowania miejskie Krakowa $z$ zamkiem na Wawelu czy posadzka w formie szachownicy, mimo że maja znaczenie symboliczne dotyczace istoty władzy królewskiej, nie zostały odwzorowane na rewersie medalu z 1697 r. Inskrypcję otokowa projektu awersu medalu, autorstwa Duvena: SERVAVI ET MERVI (służyłem i zasłużyłem), należy natomiast łączyć $z$ zasługami Jana III Sobieskiego dla Rzeczpospolitej.

Następny medal koronacyjny Augusta II, sygnowany u dołu na rewersie I. K. z około 1697 r., niewiele odbiega od programu artystycznego poprzednio opisanych dzie⿰57 ${ }^{57}$ Także i tu występują dwa najbardziej powszechne elementy kompozycji artystycznej, czyli portret monarszy (na awersie) i insygnia koronacyjne (na rewersie). Odzienie królewskie Augusta II oddane przez artystę przy okazji realizacji zamówienia królewskiego przypomina w zasadzie ubiór monarszy znany $z$ awersów poprzednich dzieł medalierskich. Sprawny oglądający dostrzeże cztery najważniejsze elementy dowodzace o związkach ikonografii starożytnej z nowożytną. Sa to mianowicie: wieniec laurowy na głowie i płaszcz udrapowany na wzór rzymskiego paludamentu spięty na lewym ramieniu okrągła brosza, cyzelowany i grawerowany kirys oraz widoczny fragmentarycznie naramiennik folgowy w kształcie pysku lwa lub głowy maszkarona.

${ }^{56}$ Gdańsk, Biblioteka PAN, rkps, sygn. Ms. 2442; E. Iw a noyko, Godfryd Peschwitz - emblematyk gdański drugiej połowy XVII wieku, „Rocznik Historii Sztuki” 1985, t. XV, s. 231-246.

57 E. Raczyński, op. cit., t. II, poz. 280. 
Twórca rewersu natomiast przypomniał odbiorcy o wyglądzie najważniejszych insygniów koronacyjnych, mianowicie: korony clausa oraz berła i miecza. Napis otokowy: REGET ET DEFENDET (Będzie panował i bronił) należy odczytywać jako twórcze rozwinięcie programu politycznego władcy-elekta. Charakterystyczne jest ustawienie zwłaszcza dwóch ostatnich insygniów skrzyżowanych ze sobą wewnattrz korony clausa. Znany jest przykład rewersu numizmatu $z$ czasów Sobieskiego z 1676 r., powstałego w warsztacie anonimowego twórcy, uświetniającego podpisanie rozejmu $z$ imperium tureckim pod Żurawnem (17 października 1676 r. $)^{58}$. Medalier na rewersie pracy zamiast berła i miecza koronacyjnego umieścił jednak wewnątrz korony aperta, nie clausa, dwie skrzyżowane gałazki oliwne. Omawiana strona medalu jest wiernym powtórzeniem impresy identyfikującej księcia mediolańskiego Franciszka II Sforzę i ilustrującej dzieło Jacoba Typotiusa, Symbola Divina et Humana..., wydane w Pradze między 1601 a 1603 r. ${ }^{59}$

Ostatni $z$ medali, pozbawiony daty oraz sygnatury autorskiej, sporządzono $z$ całą pewnością dopiero po 1 listopada 1705 r. ${ }^{60}$ (il. 8). Postać Augusta II Wettyna w długiej peruce $z$ trefionymi włosami, koszuli spodniej, bogato cyzelowanej zbroi składającej się $z$ kirysu urozmaiconego główka gorgoneionu (na piersiach) i przepasanego wstęga orderowa, opachy i nałokcica (ochraniających lewę ramię) oraz narzuconym na ramiona płaszczu gronostajowym spiętym na lewym ramieniu horyzontalna zapona $z$ wyszytym po zewnętrznej stronie Orderem Orła Białego upamiętniono w formie popiersia na awersie. Wzmiankowany order ustanowił August II Wettyn na zamku w Tykocinie, 1 listopada 1705 r. Order pierwotnie przeznaczony był dla magnatów, którzy wsparli elektora saskiego w jego staraniach o polski tron elekcyjny. Inskrypcja otokowa: FRID[ericus] AUGUSTUS II REX POLON[iae] ELECT[or] SAXON[iae] (Fryderyk August król polski elektor saski) zawiera tytulaturę dysponenta.

Do naszych czasów zachował się malarski konterfekt Augusta II Wettyna, pędzla Louisa de Silvestre'a datowany na rok 1718, prze-

${ }^{58}$ Kraków, Muzeum Narodowe, nr inw. MNK VII-Md-627; Warszawa, Muzeum Narodowe, nr inw. 16448 MNW; Własność prywatna. Przedmiot wystawiony na aukcji WCN 23 XI 1996 r. (kat. nr 732).

59 J. Ty potiu s, Symbola Divina et Humana Pontificum, Imperatorum, Regum..., t. I, Pragae (Praga) 1601, s. 25.

${ }^{60}$ Drezno, Państwowe Zbiory Sztuki, Gabinet Numizmatyczny, nr inw. BGB 8835, E. Raczyński, op. cit., t. II, poz. 261. 
chowywany w poznańskim Muzeum Narodowym ${ }^{61}$ (il. 9). Obraz ten wykazuje wiele cech wspólnych $z$ medalierskim wizerunkiem monarchy. Władca sportretowany został w ujęciu en trois quarts $z$ głowa zwrócona lekko w lewo, na ciemno szarym tle. Ubiór królewski wygląda następująco. Na stalowy kirys $z$ wyeksponowanym naramiennikiem folgowym podbitym od spodu czerwona materią obrzeżona złotym paskiem wraz $z$ nałokcicem i przewieszona przezeń wstęgę orderową narzucony został płaszcz gronostajowy udekorowany wyszyta gwiazda orderu Orła Białego, uzupełniona o dewizę: Pro Fide, Lege et Rege i spięty na lewym ramieniu podłużną broszą. Natomiast w charakterze okrycia spodniego występuje biała koszula, której fragment utrwalił artysta na wysokości szyi. Istnieje szereg podobieństw między dziełem malarskim a medalierskim. W obydwu przypadkach podobnie udrapowany jest np. wymieniony płaszcz gronostajowy spięty na lewym ramieniu podłużna zapona $z$ kamieniami szlachetnymi (na awersie medalu jednak całkowicie zasłaniający część naramiennika). Także typ zbroi preferowany przez modela wydaje się zbliżony. Niewattpliwie jednak naramiennik folgowy na wizerunku medalierskim ma liczne zdobienia, których pozbawiony jest jego odpowiednik na konterfekcie malarskim. Na uwagę zasługuje również królewska fryzura. Interesujący jest zwłaszcza najdłuższy kosmyk włosów królewskich zakończony niewielkim supełkiem, spływający na naramiennik królewski. Identyczny kosmyk $z$ supełkiem, choć w innym miejscu, bo na samym kirysie obok gorgoneionu (na piersiach kirysa), oglądający odnajdzie na wizerunku medalierskim na awersie.

Po analizie zebranego materiału ikonograficznego $z$ początków panowania Augusta II Wettyna nasuwają się pewne spostrzeżenia, którymi warto podzielić się $z$ czytelnikiem. Po pierwsze, należy zauważyć, że możemy wyróżnić dwa typy portretów królewskich dominujących na medalowym krążku:

1. Portret all'antica, którego głównymi elementami są wieniec laurowy czy też stylizowany na starożytny kompletny ubiór w postaci hełmu $z$ pióropuszem, naramiennika $z$ paskami pteryges, tzw. rzymskiego fartuszka $z$ paskami cingulum i wysokich rzemiennych sandałów. Nie bez znaczenia, tak jak w przypadku np. medalu nieznanego autora pozbawionego daty emisji, było także

${ }^{61}$ Poznań, Muzeum Narodowe, in. inw. Mo 2187. 
ustawienie głowy królewskiej w prawym profilu wyrażającym majestat i wysoka pozycję portretowanego.

2. Portret współczesny, na który składa się XVIII-wieczny ubiór władcy $\mathrm{w}$ postaci długiej peruki $\mathrm{z}$ trefionymi włosami, koszuli spodniej i bogato cyzelowanej zbroi składającej się z kirysu urozmaiconego główka gorgoneionu, opachy i nałokcica (ochraniających lewę ramię) oraz narzuconego na ramiona płaszczu gronostajowego spiętego na lewym ramieniu zapona wraz $z$ orderem orła białego i wstęga orderową (pod płaszczem).

Ilościowo przeważaja medalierskie wizerunki władcy nawiązujace do współczesnych dzieł malarskich czy graficznych. Niemniej należy zadać pytanie o powód emisji nielicznych monet i medali Augusta II Wettyna z podobizna królewska all'antica. Wettyn - jak się wydaje - pragnął $\mathrm{w}$ tym względzie nawiązywać do ikonografii medali królewskich Jana III Sobieskiego. Prawdopodobnie te same motywy działania kierowały Augustem II w momencie zamawiania medalu pozbawionego sygnatury twórcy i pochodzącego z $1697 \mathrm{r}$. $\mathrm{Na}$ awersie omawianej pracy artysta sporządził podobiznę jeźdźca, zapewne samego króla, przemieszczającego się na koniu w staropolskim płaszczu - delii i kołpaku.

Natomiast najpewniej punktem odniesienia dla twórców medali $z$ podobizna Wettyna we współczesnym ubiorze zachodnioeuropejskim były malowane równolegle konterfekty malarskie. Wystarczy przypomnieć w tym miejscu o licznych analogiach łączaccych awers medalu pozbawionego daty oraz sygnatury autorskiej sporzadzonego jednak $z$ cała pewnościa po 1 listopada 1705 r. i portret królewski z 1718 r. pędzla Louisa de Silvestre'a. Być może wymieniony portret jest wersja nieistniejącego wcześniejszego dzieła tego samego artysty reprodukowanego np. za pośrednictwem grafiki. Wykluczyć należy jednak, że to medalierski wizerunek stał się wzorem dla malarza.

Przechodząc do tematyki rewersów medali uwzględnionych $\mathrm{w}$ artykule, należy wymienić medale o charakterze:

1. Heraldycznym (np. niesygnowany medal z 1697 r., na rewersie którego znajduja się artystycznie rozwiązane herby Korony, Wielkiego Księstwa Litewskiego oraz dynastii Wettynów).

2. Mitologiczno-alegorycznym (np. medal autorstwa Georga Hautscha $z 1697$ r. zawierajacy na rewersie podobizny: Herkulesa i personifikacji Polski Polonię). 
3. Emblematycznym (np. medal pozbawiony daty zaopatrzony w sygnaturę autorską: G. L. F., na którego rewersie oglądający dostrzeże insygnia władzy Augusta II: koronę clausa, berło oraz dwa miecze elektorskie nawiąujace do herbu elektorów Saksonii, spoczywające na postumencie w kształcie ściętego filaru bądź kolumny, oraz napis u góry: HONORE, TIMORE [Czcią, bojaźnia]).

4. Genealogicznym (np. medal, datowany na rok 1697 i sygnowany na awersie: C. W. [Christian Wermuth?], którego rewers wypełnia drzewo genealogiczne $z$ inskrypcjami dotyczacymi Augusta II i jego przodków połączonymi wicią drzewa wawrzynu).

Podstawowym celem przekazu propagandowego wszystkich wymienionych medali było uzasadnienie praw dotychczasowego elektora saskiego do tronu polskiego. Odbiorca po nawet pobieżnym zapoznaniu się $z$ przedstawionym materiałem medalierskim mógł utwierdzić się w przekonaniu co do znakomitego pochodzenia Augusta II i jego antenatów (np. medal, datowany na $1697 \mathrm{r}$. i sygnowany na awersie: C. W. [Christian Wermuth?]), licznych przymiotów panującego utożsamianego $z$ Herkulesem (np. medal autorstwa Georga Hautscha z 1697 r.) czy heraldycznych związków między herbem Wettynów a oficjalnymi emblematami Korony i Litwy (np. niesygnowany medal z 1697 r.). Jak już zostało wspomniane, władca $\mathrm{w}$ razie takiej potrzeby, mimo że osobiście hołdował modzie zachodnioeuropejskiej, nie uchylał się od promowania za pośrednictwem medali królewskich sarmackiego modelu życia. Bez watpienia tego typu zabiegi były konieczne do utwierdzenia władzy Augusta II Wettyna, który swą przewage w rozgrywkach elekcyjnych nad konkurentami zawdzięczał jedynie sile przewagi wojska saskiego.

\section{Bibliografia}

\section{ŹRÓDEA RĘKOPIŚMIENNE}

Albertrandy J., Historya polska ostatnich trzech wieków medalami zaświadczona i objaśniona, rękopism około 200 w polskim języku skreślony, a częścia i po francuzku napisany, znajdowat się $w$ bibliotece $b$. Warszawskiego Towarzystwa przyjaciół nauk, [b.m. i d.w], Poznań, Biblioteka Raczyńskich, sygn. Rkp 4. 


\section{$\dot{Z}_{\text {RÓDEA DRUKOWANE }}$}

Albertrandy J., Album rycin medali $i$ monet $z$ płyt przygotowanych do dzieła x. Biskupa Jana Albertrandego w latach 1822-1828 znajdujacych sie obecnie w Akademii Sztuk $w$ Petersburgu, [b.m. i d.w.], Poznań, Muzeum Narodowe, Gabinet Numizmatyczny (księgozbiór podręczny), nr inw. 7465a.

Bentkowski F., Spis medalów polskich lub z dziejami krainy polskiej stycznych, $w$ gabinecie Król. Alex. Uniwersytetu $w$ Warszawie znajdujacych się, tudzież ze zbiorów i pism rozmaitych lub podań zebrany i porzadkiem lat ułożony, Warszawa 1830.

Köhler J.D., Der wöchentlichen historischen Münz-Belustigung... Stück: darinnen allerhand merckwürdige und rare Thaler, Ducaten, Schaustücken, andere sonderbahre Gold- und Silber-Münzen: nebst einer Vorredevon Joh. Luckii Sylloge Numismatu, Bd. I-XXII, Nürnberg 1729-1750.

Loon G. von, Beschryving der Nederlandsche Historiepenningen, Bd. IV, Graavenhaage (Haga), München 1723, Bayerische Staatsbibliothek, sygn. 2 Num. rec. $28 \mathrm{w}-\mathrm{B}, 1$.

\section{Opracowania}

Bahrfeldt E., Die Münzen und Medaillen Sammlung in der Marienburg, Bd. I-VI, Danzing-Königsberg 1910.

Bartynowski W., Teki Bartynowskiego: Medale z czasów Jana III, b.m.w. [XIX/ $\mathrm{XX}$ w.].

Chojecka E., Dekoracja malarska ksiag promotionum i diligentiarum Uniwersytetu Jagiellońskiego XVI-XVII wieku, Kraków 1965.

Chelmiński S., Sammlung des Herrn Sigismund von Chelminski, Szarawka (Russland). Münzen und Medaillen von Polen und sonstige auf Polen bezügliche Gepräge: die öffentliche Auction findet statt: Montag, den 25 April 1904 und folgende Tage, hrsg. S. von Chelminski, O. Helbing, München 1904.

Chwała $i$ sława Jana III $w$ sztuce $i$ literaturze. Katalog wystawy jubileuszowej $z$ okazji trzechsetlecia odsieczy wiedeńskiej. Warszawa (Wilanów) wrzesieńgrudzień 1983, red. W. Fijałkowski, J. Mieleszko, Warszawa 1983.

Dernałowicz M., Portret Familii, Warszawa 1990.

Dunin-Borkowski J.S., Dunin-Wąsowicz M., Elektorowie królów Władysława IV, Michała Korybuta, Stanisława Leszczyńskiego i spis stronników Augusta III, Lwów 1910.

Dutkowski J., Corpus Nummorum Gedanensis. Katalog i cennik monet, medali i żetonów gdańskich i z Gdańskiem zwiazanych 1200-1998, Gdańsk 2000.

Dutkowski J., Złoto czasów dynastii Wazów, Gdańsk 2015.

Estreicher K., Bibliografia polska, t. I-XXXIII, Kraków 1870-1939.

Gumowski M., Medale Władysława IV, „Wiadomości Numizmatyczno-Archeologiczne" 1939, t. XX, s. 2-136.

Gumowski M., Sztuka medaljerska w Polsce i jej rozkwit, Warszawa 1924.

Historia Gdańska, t. III, cz. 1 (1655-1793), red. E. Cieślak, Gdańsk 1993. 
Hutten-Czapski E., Catalogue de la collection des médailles et monnaies polonaises du comte E. Hutten-Czapski, t. I-V, St. Petersbourg-Cracovie 1871-1916.

Iwanoyko E., Godfryd Peschwitz - emblematyk gdański drugiej połowy XVII wieku, „Rocznik Historii Sztuki” 1985, t. XV, s. 231-246.

Kamiński C., Kowalczyk W., Medale i medaliony polskie i zwiazane z Polska. Katalog wystawy, Warszawa 1969.

Katalog portretów osobistości polskich i w Polsce działajacych w zbiorach Biblioteki Narodowej, red. H. Widacka, t. I-VIII, Warszawa 1990-1999.

Kolekcja generała Jerzego Wesierskiego. Katalog monet i medali, red. A. Białkowski, E. Tarka, S. Suchodolski, Z. Wdowiszewicz, Muzeum Narodowe, Warszawa 1974.

Łomnicka-Żakowska E., Graficzne portrety Augusta II i Augusta III Wettynów w zbiorach Muzeum Narodowego w Warszawie, Warszawa 1997.

Łomnicka-Żakowska E., Grafika portretowa epoki saskiej $w$ Polsce $w$ relacji z późnobarokowa grafika europejska, Warszawa 1997.

Manthey J., Le bienheureux Innocent XI et La Pologne „Boulevard de la Chrétienté” sur les medailles commemoratives: de "Dextera tua Domine percussit inimicum” (1683) à „Pax fundata cum Moschis” (1686), èd. J. Gawlina, Roma 1956.

Napierała P., Die polnisch-sächsische Union (1697-1763) - Polens letzte Hoffnung - Sachsens Traum von der Macht, [w:] Polen un Deutschland Zusammenleben und -wirken, hrsg. M. Ziółek, M. Tomaszewska, Poznań 2006, s. 60-66.

Odsiecz wiedeńska. Wystawa jubileuszowa w Zamku Królewskim na Wawelu w trzechsetlecie bitwy, t. I-II, red. A. Franaszek, K. Kuczman, Kraków 1990.

Pod jedna korona. Kultura i sztuka w czasach unii polsko-saskiej, Zamek Królewski w Warszawie, 26 czerwca- 12 października 1997, red. M. Męclewska, B. Grątkowska-Ratyńska, Warszawa 1997.

Raczyński E., Gabinet medalów polskich oraz tych, które się dziejów Polski tycza poczawszy od najdawniejszych aż do końca panowania Jana III (1513-1696), t. I, Wrocław 1838.

Raczyński E., Gabinet medalów polskich oraz tych, które się dziejów Polski tycza poczawszy od wstapienia na tron Augusta II aż do zgonu syna jego Augusta III (1697-1763), t. II, Wrocław 1841.

Stahr M., Medale polskie i z Polska zwiazane od XVI do XVIII wieku, Poznań 2008.

Stahr M., Medale Wazów w Polsce (1587-1668), Wrocław-Warszawa-Kraków 1990.

Staszewski J., August II Mocny, Wrocław 1998.

Strzałkowski J., Słownik medalierów polskich i z Polska zwiąanych (1508-1965), Warszawa 1982.

Szwagrzyk J., Moneta, medal, order, Wrocław 1971.

Tervarent G., Attributs et symboles dans l'art profane 1450-1600: dictionnaire d'un langage perdu, Geneve 1958.

Thieme U., Becker F., Allgemeines Lexikon der bildenden Künstler von der Antike bis zur Gegenwart [...], t. I-XXVII, Leipzig 1907-1950.

Typotius J., Symbola Divina et Humana Pontificum, Imperatorum, Regum..., t. I, Pragae (Praga) 1601, Illinois, University of Illinois, sygn. vol. I: A-L M. 
Typotius J., Symbola Divina et Humana Pontificum, Imperatorum, Regum..., t. II, Pragae (Praga) 1602, Illinois, University of Illinois, sygn.. vol. II: pi B-Q [R].

Typotius J., Symbola Divina et Humana Pontificum, Imperatorum, Regum..., t. III, Pragae (Praga) 1603, Illinois, University of Illinois, sygn. vol. III: pi B-R S-T.

Widacka H., Jan III Sobieski w grafice XVII i XVIII wieku, Warszawa 1987.

Widacka H., Lew Lechistanu. Jan III Sobieski w grafice, Warszawa 2010.

Zbiory Poznańskiego Towarzystwa Przyjaciół Nauk w Muzeum Narodowym w Poznaniu. Katalog wystawy, red. Z. Białłowicz-Krygierowa, M. Warkoczewska, Poznań 1982.

Jan Gustaw Rokita

CARdinal Stefan Wyszyński University in WarsaW

\section{Coronation medals of August II Wettin in confrontation with contemporary works of pictorial and graphical art and with the medallist heritage of Jan III Sobieski Iconographic remarks}

\footnotetext{
$\mathrm{T}$ he author describes sixteen examples of works of medal-making, painting, graphic and sculptural art related to the title medals. As the author shows, the aim of the medals described in the article was to justify the rights of the former Saxon elector to the Polish throne. The recipient, after even a cursory glance With the presented medal material, he could prove himself convinced of the excellent origin of August II and his ancestors (e.g. the medal, dated 1697 and signed on the obverse: C. W. [Christian Wermuth?]), the numerous qualities of the reigning Hercules (e.g. the medal by Georg Hautsch from 1697) or the heraldic connections between the Wettyn coat of arms and official emblems of the Crown and Lithuania (e.g. an unsigned medal from 1697). The author also distinguished and analysed in detail medals of heraldic, mythological-alegoric, emblematic and genealogical character. He also explained the reasons why in the preserved medallic legacy of Augustus II the medals on which the Saxon ruler was perpetuated prevailed in Western European costume, and not - as in the case of medal-making works carried out at the order of the Sobieski royal court - in the dress modelled on antiquity.
}

Keywords: medal, obverse, reverse, August II Wettin, coronation. 

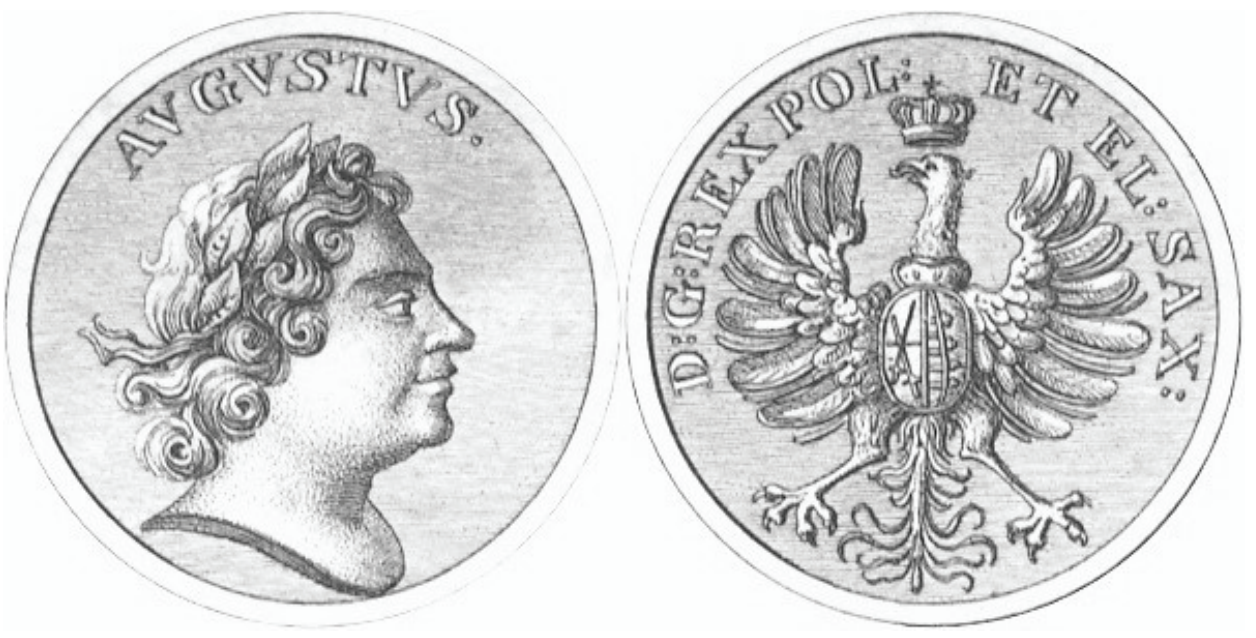

1. Medal koronacyjny Augusta II Wettyna,

brak sygnatury autora, brak daty emisji, rycina

(Źródło: Gabinet medalów polskich oraz tych, które się dziejów Polski tycza poczawszy od wstapienia na tron Augusta II aż do zgonu syna jego Augusta III [1697-1763], t. II, Wrocław 1841, poz. 262)
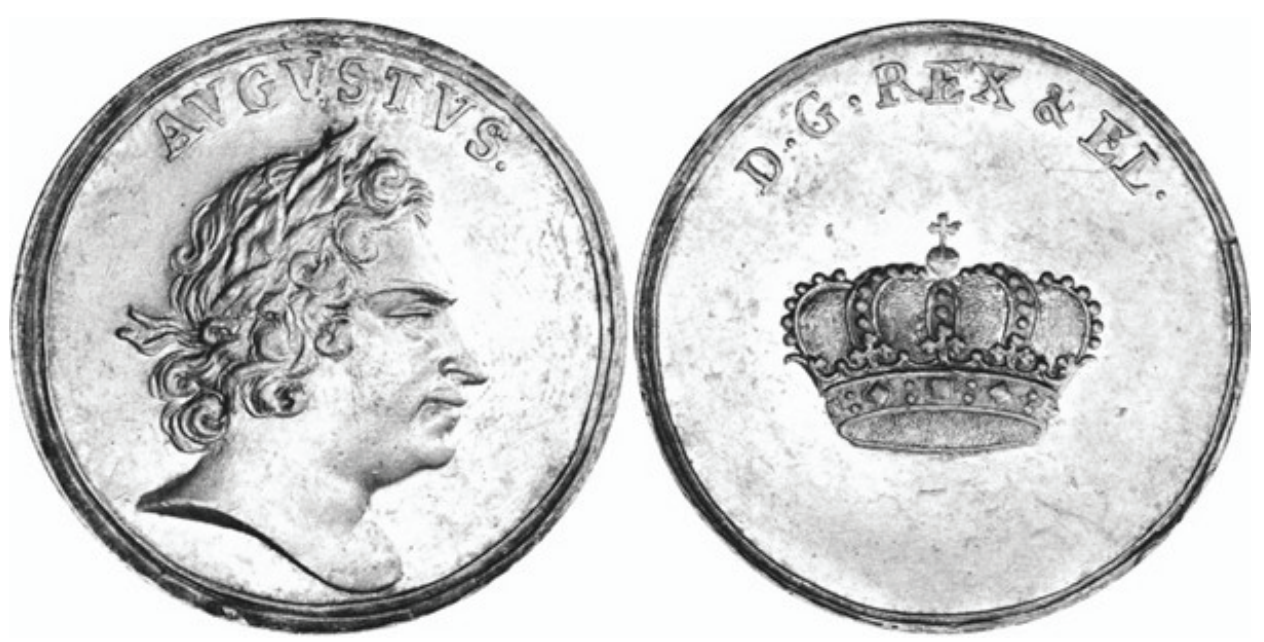

2. Medal koronacyjny Augusta II Wettyna,

brak sygnatury autora, brak daty emisji, rycina

(Źródło: Gabinet medalów polskich oraz tych, które się dziejów Polski tycza poczawszy od wstapienia na tron Augusta II aż do zgonu syna jego Augusta III [1697-1763], t. II, Wrocław 1841, poz. 263) 

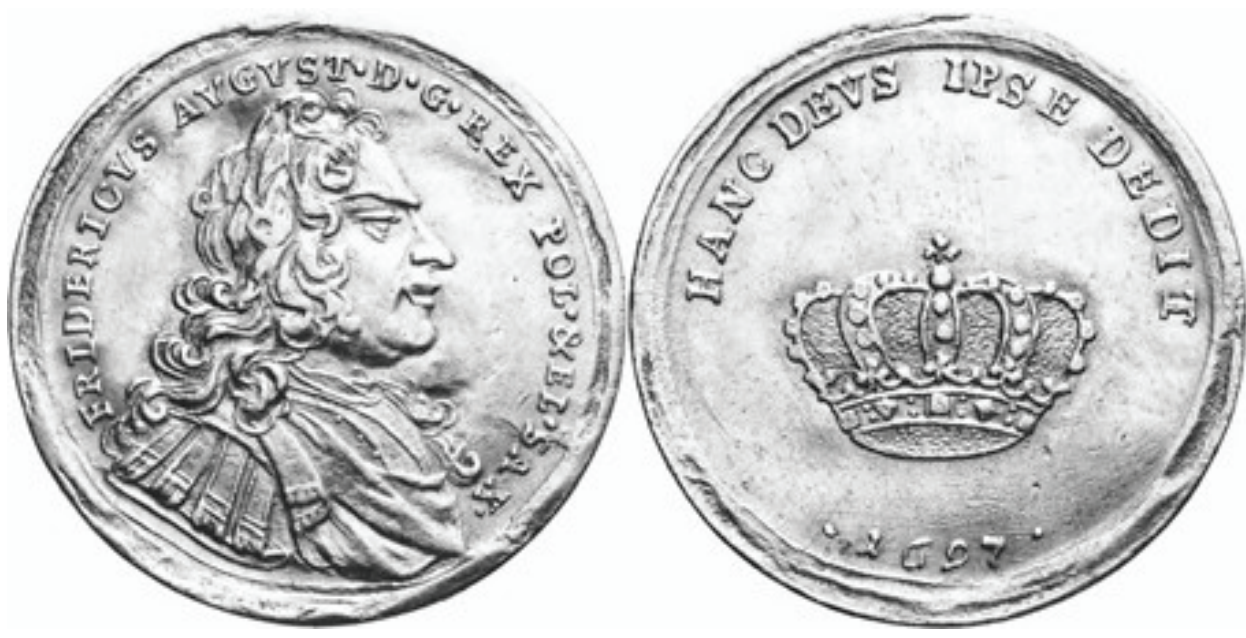

3. Medal koronacyjny Augusta II Wettyna, brak sygnatury autora, 1697, rycina (Źródło: Gabinet medalów polskich oraz tych, które się dziejów Polski tycza poczawszy od wstapienia na tron Augusta II aż do zgonu syna jego Augusta III [1697-1763], t. II, Wrocław 1841, poz. 277)
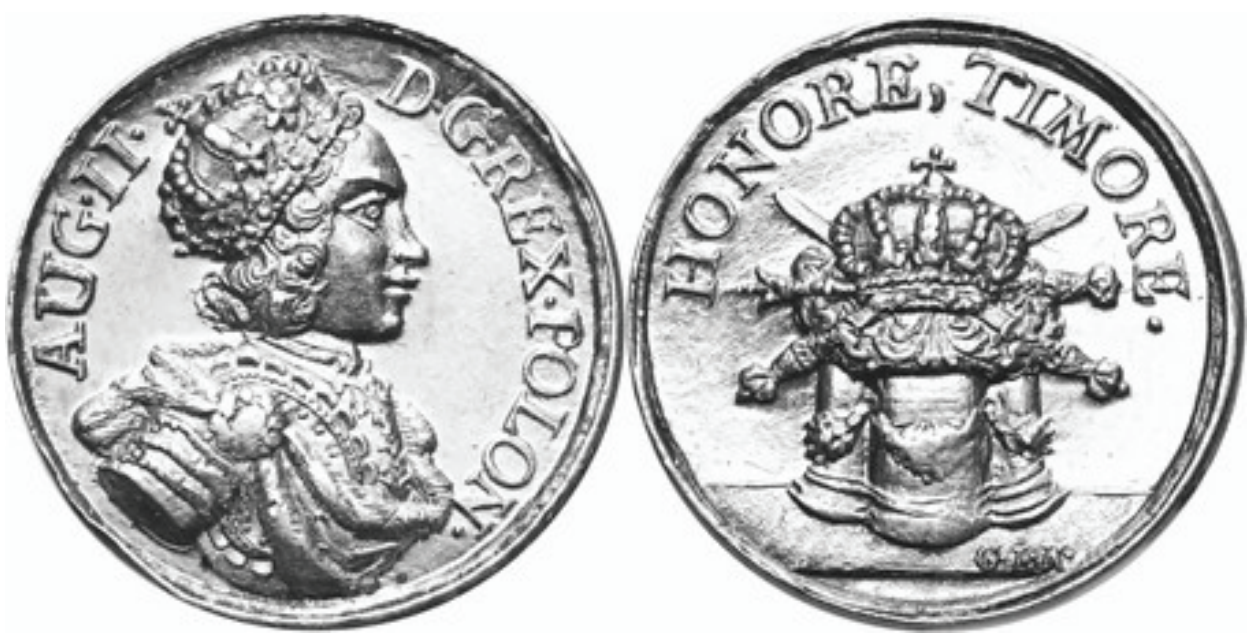

4. Medal koronacyjny Augusta II Wettyna, sygnatura autorska: G. L. F., 1697, śr. 15,5 mm, srebro, bity. Własność prywatna. Przedmiot wystawiony na aukcji antykwariatu „Gabinet numizmatyczny Damiana Marciniaka”

(Gdańsk) 10 lutego 2018 r. (aukcja 4, kat. nr 1359)

(Źródło: Gabinet medalów polskich oraz tych, które się dziejów Polski tycza poczawszy od wstapienia na tron Augusta II aż do zgonu syna jego Augusta III [1697-1763], t. II, Wrocław 1841, poz. 264) 

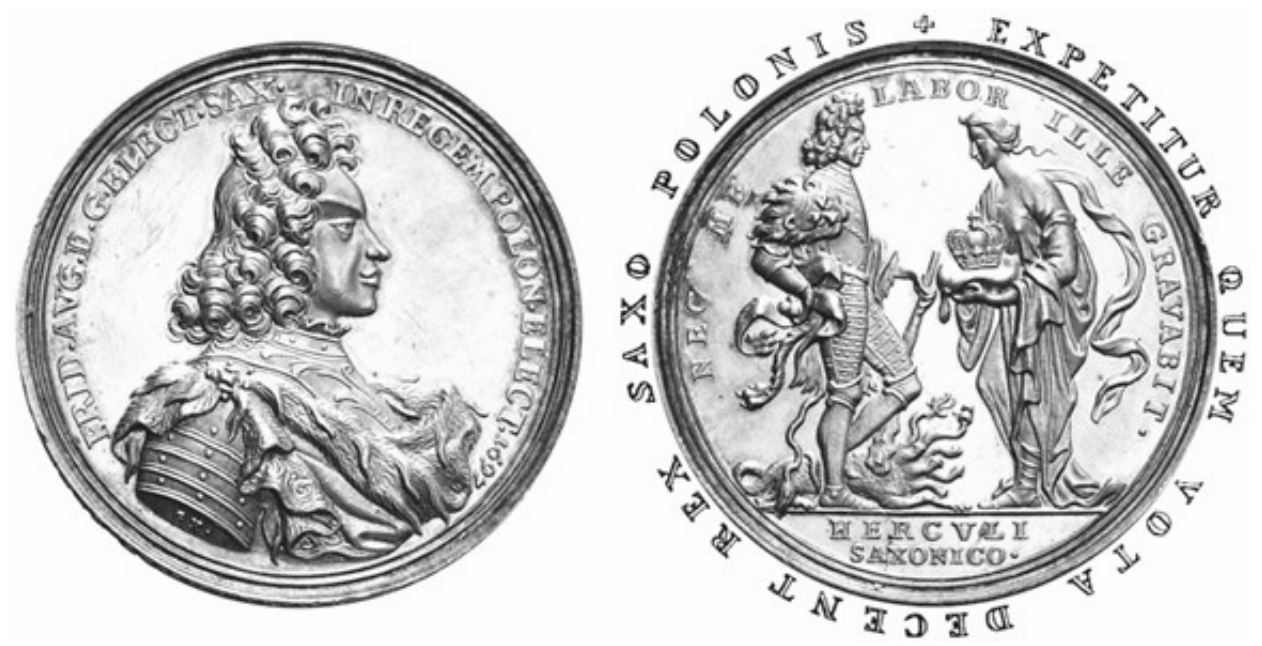

5. Medal koronacyjny Augusta II Wettyna, sygnatura autorska: Georg Hautsch, 1697, śr. 43,2 mm, srebro, bity,

(Źródło: Gabinet medalów polskich oraz tych, które się dziejów Polski tycza poczawszy od wstapienia na tron Augusta II aż do zgonu syna jego Augusta III [1697-1763], t. II, Wrocław 1841, poz. 265)
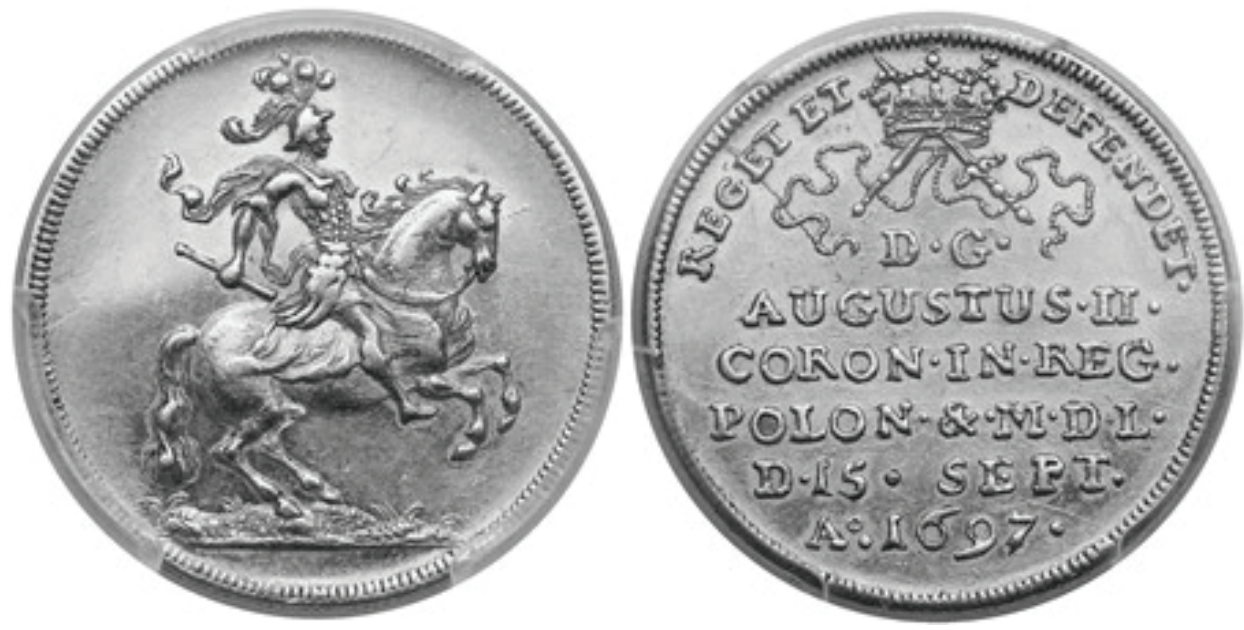

6. Medal koronacyjny Augusta II Wettyna o wartości dukata, brak sygnatury autora, 1697, śr. 23 mm, złoto, bity. Własność prywatna. Przedmiot wystawiony na aukcji „Gabinet Numizmatyczny Damian Marciniak”

(Gdańsk) 2 września 2017 r. (aukcja 2, kat. nr 245)

(Źródło: https: / / www.acsearch.info/search.html?id=4313099) 

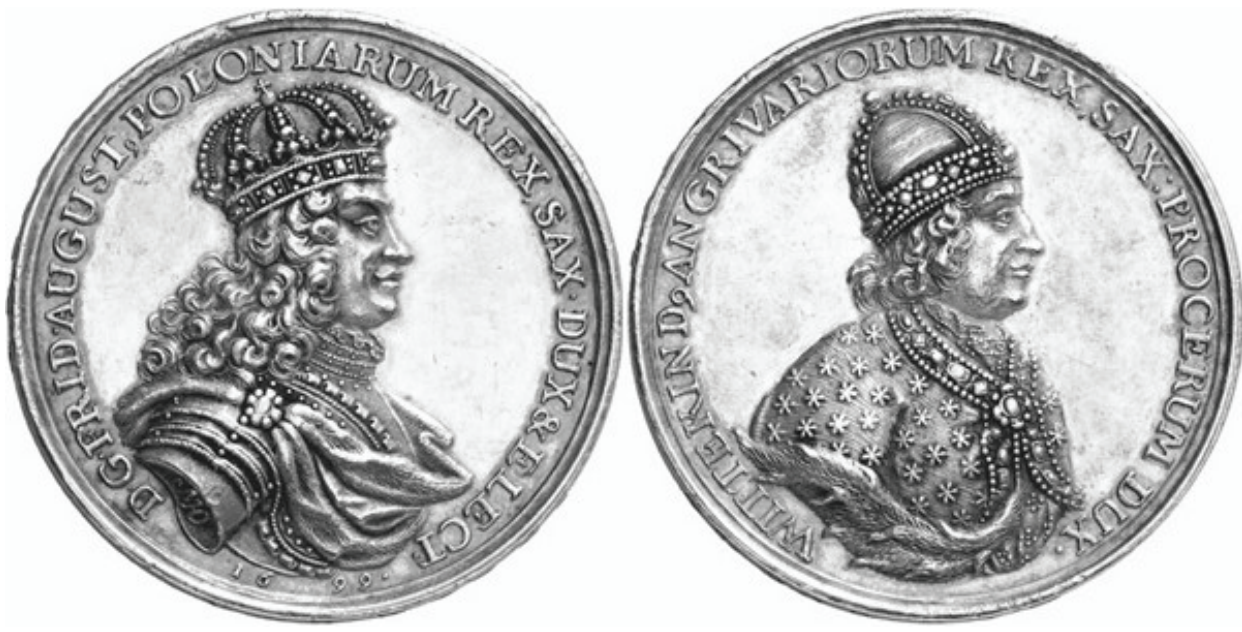

7. Medal koronacyjny Augusta II Wettyna, Martin Heinrich Omeis, brak daty emisji, śr. 43,96 mm, srebro, bity. Własność prywatna.

Przedmiot wystawiony na aukcji „Fritz Rudolf Künker GmbH \& Co. KG”

(Osnabrück) 28 września 2015 r. (aukcja 266, kat. nr 1499)

(Źródło: https: / / www.acsearch.info/search.html?id=2644460)

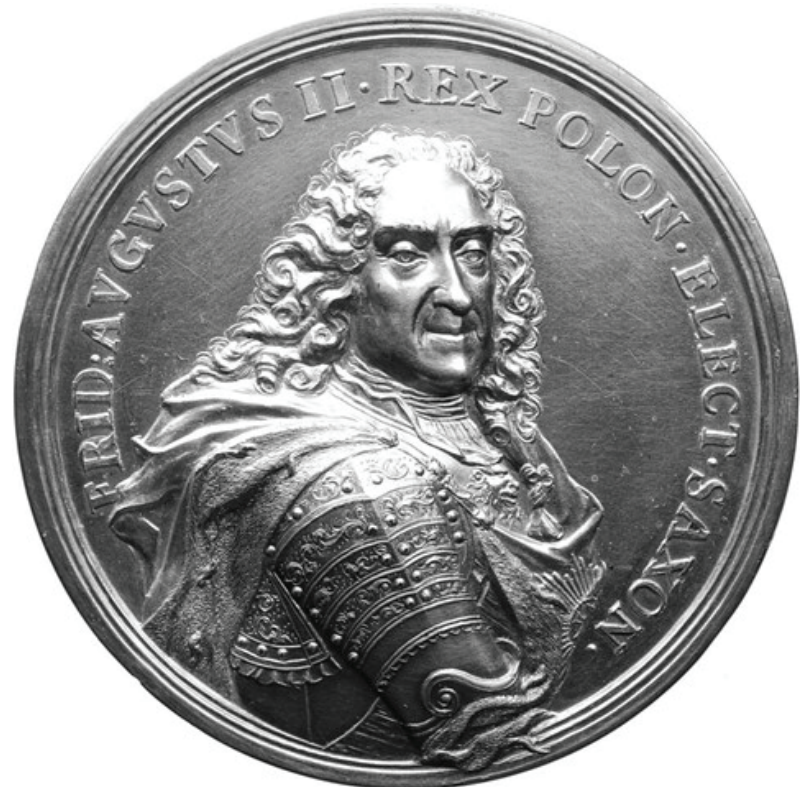

8. Medal koronacyjny Augusta II Wettyna, brak sygnatury autora, po 1 listopada 1705 r. Drezno, Państwowe Zbiory Sztuki, Gabinet Numizmatyczny, nr inw. BGB8835

(Źródło: Gabinet medalów polskich oraz tych, które się dziejów Polski tycza poczawszy od wstapienia na tron Augusta II aż do zgonu syna jego Augusta III [1697-1763], t. II, Wrocław 1841, poz. 261) 


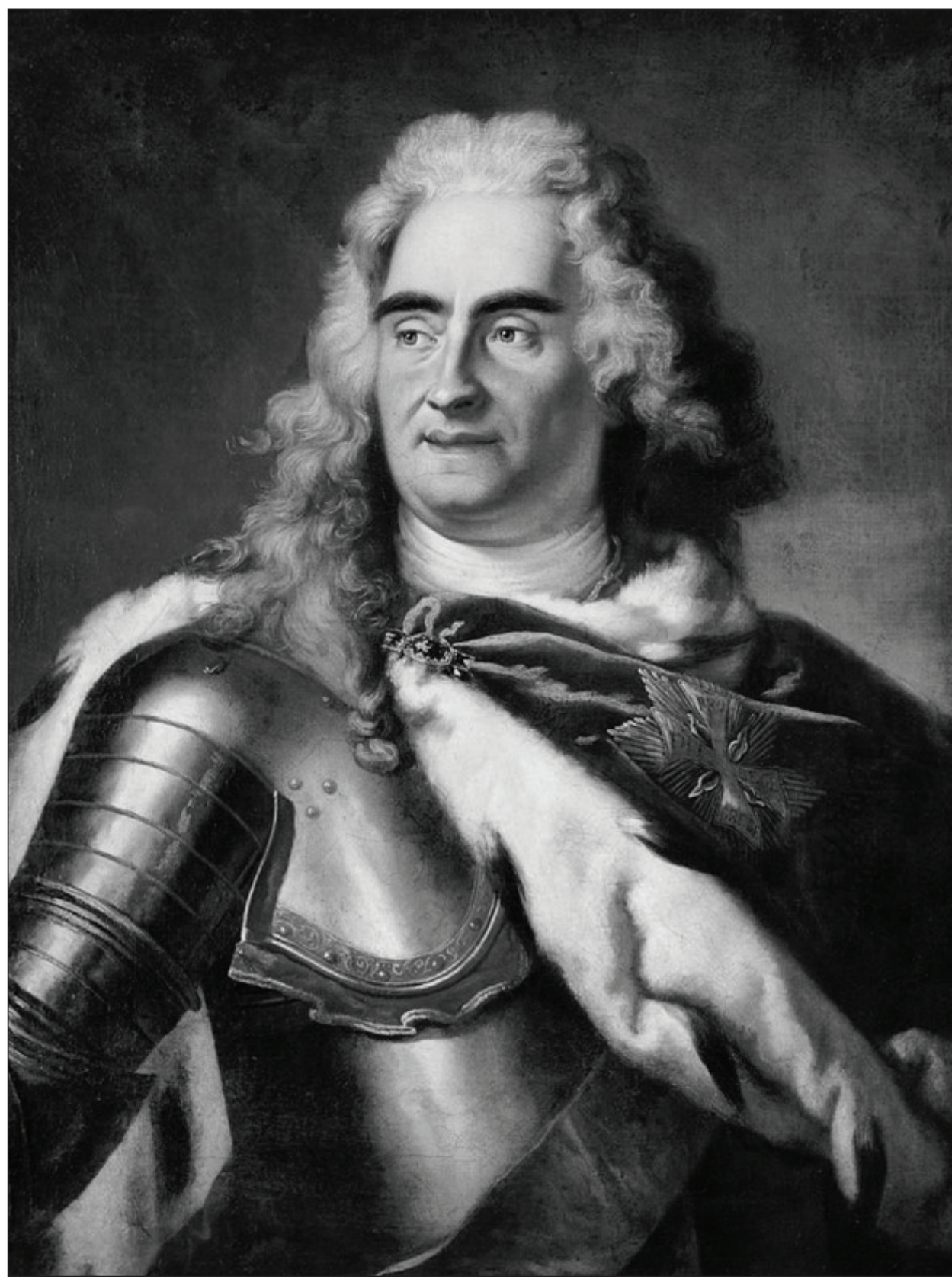

9. Konterfekt Augusta II Wettyna,

Louis de Silvestre, 1718 r., wym. 81 x $63 \mathrm{~cm}$, płótno, olej (Źródło: https: / / pl.wikipedia.org/wiki/August_II_Mocny\#/media/Plik: National_Museum_in_Poznan_-_Augustus_II.JPG) 